\title{
Botany for Gentlemen: Erasmus Darwin and "The Loves of the Plants"
}

\section{Citation}

Browne, Janet. 1989. Botany for gentlemen: Erasmus Darwin and "The Loves of the Plants". Isis 80, no. 4: 593-621.

\section{Published Version}

http://dx.doi.org/10.1086/355166

\section{Permanent link}

http://nrs.harvard.edu/urn-3:HUL.InstRepos:3353945

\section{Terms of Use}

This article was downloaded from Harvard University's DASH repository, and is made available under the terms and conditions applicable to Other Posted Material, as set forth at http:// nrs.harvard.edu/urn-3:HUL.InstRepos:dash.current.terms-of-use\#LAA

\section{Share Your Story}

The Harvard community has made this article openly available.

Please share how this access benefits you. Submit a story.

\section{Accessibility}




\section{KEY OF THE SEXUAL SYSTEM.}

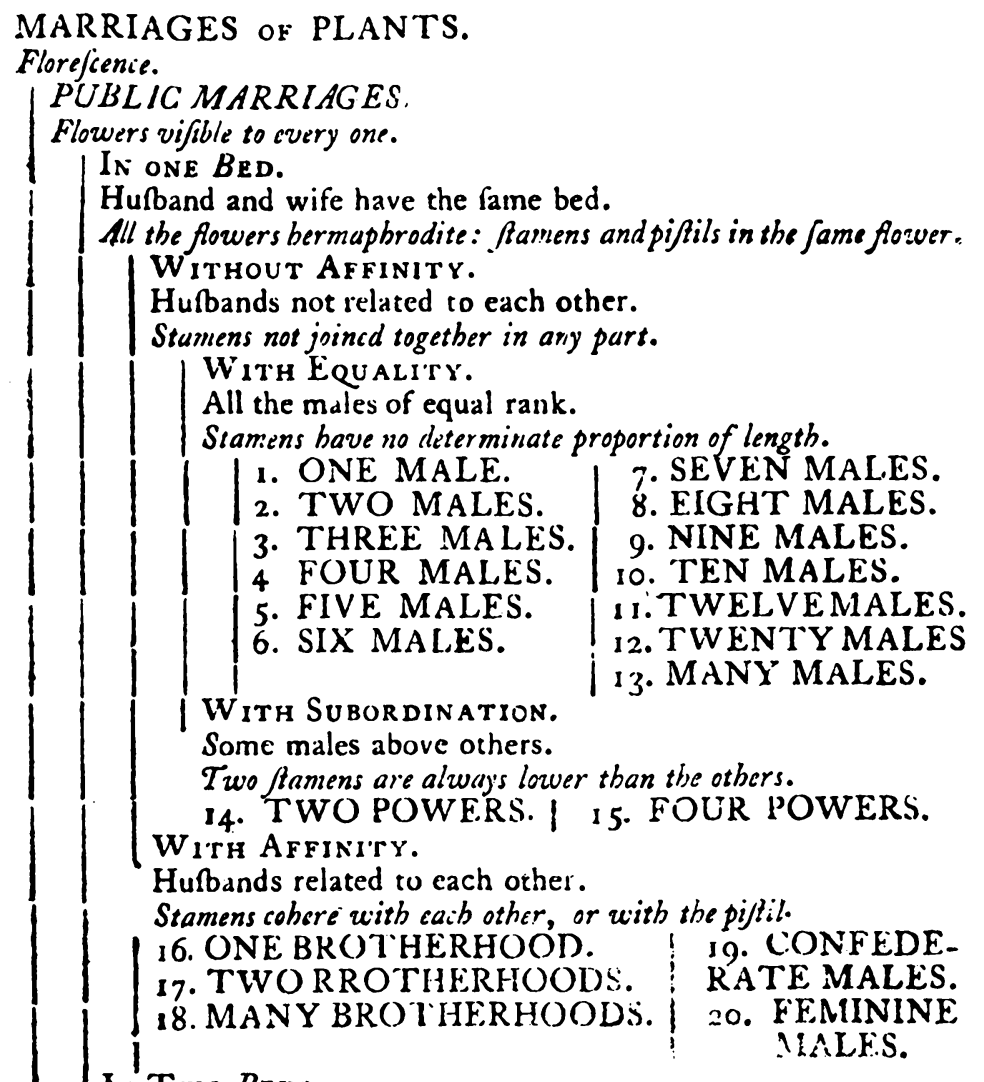

In Two BEus.

Hufband and wife have feparaic bcts.

Male flowers and fin:ale flowers in tlic fame pecics.

\begin{tabular}{l|l} 
21. ONF HOUSE. & 2.3 POL XGAIIIES. \\
22. TIV().HOUSES. &
\end{tabular}

Clandestine Marriafitis.

Flowers fcarce vifible to the naked eye.

24. CLANIISSTINE MARRIAGES

Figure 1. Erasmus Darwin's translation of a synopsis of Linnaeus's classification scheme for plants, as given in The Families of Plants (Botanical Society of Lichfield, 1787), page Ixxvii. Reproduced by permission of the Syndics of the Cambridge University Library. 


\title{
Botany for Gentlemen
}

\section{Erasmus Darwin and The Loves of the Plants}

\author{
By Janet Browne*
}

$\mathrm{H}$ ISTORIANS OF SCIENCE have long been interested in the different ways in which natural phenomena have been classified and arranged into taxonomic schemes of one kind or another. The search for "essential" characters that would yield a definition of a natural group or form, the tension between the demands of logic and the intuitive recognition of affinities, the debate over the relative merits of artificial and natural schemes, have all been topics of close attention. In recent years, however, these time-honored problems have given way to a new range of questions that focus on the social processes at work during the construction and reception of individual classification schemes; and the classification schemes themselves are being shown to represent or mirror in various ways the society that brought them into existence. Taxonomic systems of the past-particularly those found in natural history, biology, and geology - are now seen to be one of the most important resources for understanding the interconnections of science and culture.

Following work along these lines by John Dean, Adrian Desmond, Dorinda Outram, Barry Barnes, James Secord, and others, I intend to draw out some of the social commitments that underpin Erasmus Darwin's taxonomic poem, The Loves of the Plants (1789). ${ }^{1}$ Although poetry may not at first seem the most appropriate place to search for such links, literature, natural philosophy, art, and social theory were so closely integrated during the eighteenth century that natural philosophy was frequently presented in a stylized literary form, as in Oliver Goldsmith's translation of Buffon's Histoire naturelle in 1774, and the visual and literary arts were often grounded in a sophisticated awareness of the natural

\footnotetext{
* Correspondence of Charles Darwin, Manuscripts Room, University Library, Cambridge, CB3 9DR, United Kingdom; and Unit for the History of Medicine, University College, London.

I thank colleagues in the Unit for the History of Medicine, the Wellcome Institute, and the Darwin Letters Project for help with this article, as well as Sally Bragg, Heather Edwards, Joy Harvey, Desmond King-Hele, Michael Neve, Yvonne Noble, Anne Secord, James A. Secord, and the Isis referees.

${ }^{1}$ John Dean, "Controversy over Classification: A Case Study from the History of Botany," in Natural Order: Historical Studies of Scientific Culture, ed. Barry Barnes and Steven Shapin (Beverly Hills, Calif./London: Sage, 1979), pp. 211-230; Adrian Desmond, Archetypes and Ancestors: Palaeontology in Victorian London, 1850-1875 (London: Blond \& Briggs, 1982); Desmond, "The Making of Institutional Zoology in London, 1822-1836," History of Science, 1985, 23:153-185, 223-250; Dorinda Outram, "Uncertain Legislator: Georges Cuvier's Laws of Nature in Their Intellectual Context," Journal of the History of Biology, 1986, 19:323-368; Barry Barnes, Interests and the Growth of Knowledge (London: Routledge \& Kegan Paul, 1977); and James A. Secord, Controversy in Victorian Geology: The Cambrian-Silurian Dispute (Princeton, N.J.: Princeton Univ. Press, 1986).
} 
sciences of the day. Poets were philosophers, and philosophers poets. Erasmus Darwin was both of these and a physician too. The Loves of the Plants expressed its author's comprehensive interests to a marked degree, for Darwin intended it to be a vindication and explanation, both amusing and instructive, of Linnaeus's classification scheme for plants. In this work Darwin dramatized Linnaeus's system by portraying the stamens and pistils (the male and female organs) as men and women. As its title suggests, the text is about the relations between the sexes-ostensibly those pertaining to plants, as described by Linnaeus and on which he based his systematic arrangement, but in actual terms translated by Darwin into an extended account of human sexual behavior. The metaphor of personification served several functions in Darwin's poetry, and there was a vigorous interplay between Darwin's defense of Linnaeus, his commitment to evolutionary transformism, his thoughts about plants, and wide-ranging views about society and progress. Verse, in his opinion, was an appropriate and effective medium for conveying these diverse ideas.

Looking beyond the purely didactic or frivolous roles usually ascribed to the poem, I will argue that Darwin's botanical taxonomy was firmly located in his eighteenth-century world: that the metaphors he chose to explain Linnaeus's system reflected not so much his personal views on human nature as, more significantly, the views of his contemporaries as expressed through the conventional images and literary stereotypes of his time. The poetic imagery, in its turn, influenced the ways in which Darwin and his readers subsequently thought about the vital activities of plants and plant reproduction. Moreover, whereas other classification schemes might have primarily reflected contemporary culture, social class, or intellectual preoccupations, Darwin's poem is of particular interest because it included in addition ideas about the social position, behavior, and functions of women. His version of Linnaeus's system therefore offers an opportunity to study the ways in which gender and views about gender relations were manifested in scientific practice. Through his verses we can follow the expression of connections between the ordering of nature and human society and examine how Darwin's explanation of Linnaeus's scheme may have embodied, maintained, or otherwise served the conventions and objectives of an extended community of natural philosophers and intellectuals in late eighteenth-century England.

\section{ERASMUS DARWIN}

Erasmus Darwin's important position in eighteenth-century English culture was first documented some twenty years ago when Desmond King-Hele brought the "essential writings" of Darwin (1731-1802) to our attention; and through KingHele's continued interest and publications Darwin's work is now well known for its vivid pictures of evolution and cultural progress interlaced with stirring accounts of science, technology, and society during the English Industrial Revolution. ${ }^{2}$ Expansive views like these are found most obviously in Darwin's two

${ }^{2}$ See The Essential Writings of Erasmus Darwin, ed. Desmond King-Hele (London: MacGibbon \& Kee, 1968); King-Hele's earlier biography, Erasmus Darwin (London: Macmillan, 1963); King-Hele, Doctor of Revolution: The Life and Genius of Erasmus Darwin (London: Faber \& Faber, 1977); The Letters of Erasmus Darwin, ed. King-Hele (Cambridge: Cambridge Univ. Press, 1981) (hereafter Letters of Erasmus Darwin); and, most recently, King-Hele, Erasmus Darwin and the Romantic Poets 
lengthy poems The Economy of Vegetation (Part 1 of The Botanic Garden, 1791) and the posthumously published Temple of Nature (1803). Recent works by Maureen McNeil and others have situated Darwin more specifically in the social landscape of the entrepreneurial provincial science of the English midlands. ${ }^{3}$ Prominent in the Lunar Society of Birmingham, Darwin and his colleagues, among them James Keir, Josiah Wedgwood, Matthew Boulton, and Richard Lovell Edgeworth, were wealthy professional figures who had received a university education: cosmopolitan, well read, advocates for many of the views set out by the French philosophes, these were men who were by nature liberal reformers, deeply committed in one way or another to the idea of improvement in all spheres of existence through the exercise and application of natural philosophy, and who separated themselves from the political views of the Tory hierarchy and the established church without jeopardizing their respectability or status as "gentlemen." Erasmus Darwin was reputed to be an atheist and known, in later life, to be an evolutionist, but he was also a prosperous, respectable physician. To be liberal in such circles did not mean that one was a radical firebrand.

The Loves of the Plants was first issued anonymously in 1789, having been printed in Darwin's hometown of Lichfield in Staffordshire-although he himself had moved to Derby in 1781 - and was from the start meant primarily to test the water for a second, more heavyweight account of the development of the earth and society. Together, the poems would constitute a two-part set entitled The Botanic Garden. Darwin claimed he wrote The Loves of the Plants solely for the money that might come his way, hoping only to make the topic of botany agreeable to "ladies and other unemploy'd scholars," 4 and there seems no reason to deny him this practical explanation of his own motives. The intended second poem, called The Economy of Vegetation, was not published for another two years, and Darwin seems to have intended to stifle it if the first had not been successful..$^{5}$ The enthusiastic reception for The Loves of the Plants appears to have surprised even its author, who recounted his profits with great satisfaction to friends in letters and set out to complete the next part confident that his poetry was liked by most members of the polite society in which he lived and worked. ${ }^{6}$

(London: Macmillan, 1986). Before King-Hele's work on Darwin few full-length studies were available.

${ }^{3}$ Maureen McNeil, Under the Banner of Science: Erasmus Darwin and His Age (Manchester: Manchester Univ. Press, 1987); McNeil, "The Scientific Muse: The Poetry of Erasmus Darwin," in Languages of Nature: Critical Essays on Science and Literature, ed. L. J. Jordanova (London: Free Association Books, 1986), pp. 159-203; and R. E. Schofield, The Lunar Society of Birmingham (Oxford: Oxford Univ. Press, 1963).

${ }^{4}$ King-Hele, Letters of Erasmus Darwin, pp. 116-117.

${ }^{5}$ Ibid., pp. 139-140. In order of publication the poems are The Botanic Garden, Part II: Containing The Loves of the Plants, a Poem: With Philosophical Notes (Lichfield, 1789) (hereafter Darwin, Loves of the Plants) and The Botanic Garden: A Poem in Two Parts, Part I: Containing The Economy of Vegetation (London, 1791). Both poems were issued anonymously, and Erasmus Darwin did not officially confirm his authorship of the works until 1794, when, on the title page of his medical tract Zoonomia; or the Laws of Organic Life, 2 vols. (London, 1794-1796), he referred to himself as "Author of The Botanic Garden."

${ }^{6}$ See, e.g., James Keir, An Account of the Life and Writings of Thomas Day (London, 1791), pp. 112-113: "that exquisite poem, the Botanic Garden, in which the graces themselves seem to decorate the temple of science with their choicest wreaths and sweetest blossoms." King-Hele, Doctor of Revolution, pp. 197-198, summarizes the favorable reception of the Loves of the Plants; it is also discussed at length in King-Hele, Darwin and the Romantic Poets (both cit. n. 2). For Darwin's response see Letters of Erasmus Darwin, pp. 193, 196, 197. 


\section{THE SEXES OF PLANTS}

Darwin's hesitation and subsequent surprise no doubt stem from the way in which he chose to describe the sex life of flowers, for the poem was unabashedly about sex and sexual relations, about the all-pervading drive to find a mate and to reproduce. Such a focus was decidedly controversial. Darwin based The Loves of the Plants on the supposition that there are indeed male and female plants, that there are two sexes that join together for the purposes of reproduction. This idea was still, in Darwin's time, the subject of heated debate, being only partially confirmed by miscellaneous observations of plant fertilization. It was a matter of some importance in natural philosophy, because analogy with animal processes, so much a part of eighteenth-century thought, demanded some kind of corresponding sexuality in plants.

Throughout the eighteenth century naturalists had puzzled over the differing roles played by male and female parents in inheritance, in generation, and in fertilization and had attempted to understand plant reproduction through analogies with what was known about animals. ${ }^{7}$ Unlike animals, however, plants rarely convey a clear picture either of male and femaleness-most flowers possess both sets of organs-or of sexual reproduction at all, since plants are quite capable of propagating their kind by purely vegetative means, and it is hard to know which part of the organism might count as a sexual individual. ${ }^{8}$ Did a flower perhaps mate with itself, as hermaphroditic animals like snails and earthworms were popularly supposed to do, or with another flower on the same tree or bush, or with flowers of another plant altogether, thereby incurring the mechanical problem of conveying pollen from one point to another? Such differing possibilities led many naturalists to doubt the fact of sexes in plants. ${ }^{9}$ Nor was there any clear parallel to animal spermatozoa in plants, and indeed the debate between epigeneticists and preformationists had foundered on exactly that issue, one side seeing sperm as fully formed seeds scattered in a nutrifying womb, the other as dust, or pollen, merely bringing some needed animus to a receptive ovum in which the seed already resided, somewhat similar to the way in which aphids and other parthenogenetic animals duplicated themselves without much male intervention. ${ }^{10}$

By 1759 the question of plant sexuality was thought sufficiently perplexing for the Imperial Academy of Saint Petersburg to offer a prize for an essay illuminating the process of fecundation and the perfection of fruit by semen, a prize widely reported to have been proposed to draw forth the views of Linnaeus, then at the height of his considerable powers. ${ }^{11}$ And it was indeed won by Linnaeus

${ }^{7}$ Jacques Roger, Les sciences de la vie dans la pensée français du XVIIIe siècle: La génération des animaux de Descartes à l'Encyclopédie (Paris: Armand Colin, 1963); Philip C. Ritterbush, Overtures to Biology: The Speculations of Eighteenth-Century Naturalists (New Haven, Conn.: Yale Univ. Press, 1964); and François Delaporte, Nature's Second Kingdom: Explorations of Vegetality in the Eighteenth Century, trans. Arthur Goldhammer (Cambridge, Mass.: MIT Press, 1982).

${ }^{8}$ John Farley, Gametes and Spores: Ideas about Sexual Reproduction, 1750-1914 (Baltimore/ London: Johns Hopkins Univ. Press, 1982); see $\varepsilon \rightarrow$ Duncan S. Johnson, "The Evolution of a Botanical Problem: The History of the Discovery of Sexuality in Plants," Science, N.S., 1914, 39:299-319.

${ }^{9}$ See Delaporte, Nature's Second Kingdom (cit. n. 7), pp. 129-130.

${ }^{10}$ F. J. Cole, Early Theories of Sexual Generation (Oxford: Clarendon Press, 1930); Shirley Roe, Matter, Life, and Generation: Eighteenth-Century Embryology and the Haller-Wolff Debate (Cambridge: Cambridge Univ. Press, 1981); and Farley, Gametes and Spores (cit. n. 8).

11 James Edward Smith, trans., introduction to A Dissertation on the Sexes of Plants: Translated from the Latin of Linnaeus (London, 1786), pp. vii-viii. 
with his dissertation on the sexes of plants, published in Saint Petersburg the following year. ${ }^{12}$ In this work Linnaeus cited several examples of experiments in plant fertilization, carried out in Uppsala, confirming his previously expressed view that flowers were expressly organs of reproduction, present only to enable the perpetuation of species. ${ }^{13} \mathrm{He}$ also put forward the argument that plant hybrids owed their existence to a promiscuous mixing of males and females, which might also account for the origin of many vegetable species. A genus, he claimed, is nothing else than a number of plants sprung from the same mother by different fathers. ${ }^{14}$ As for inheritance, he proposed that the male partner, gave to its offspring the form of the leaves and the external parts, while the female transmitted the inside, medullary parts and the organ of fructification. ${ }^{15}$ Each sex consequently played a material role in the process of making a new individual, either of the existing specific type or some kind of hybrid novelty.

Clearly, this prizewinning essay was closely bound up with Linnaeus's often complex views on the origin and natural hierarchy of plants as expressed in his systematic writings, ${ }^{16}$ and his taxonomic schemes were soundly based on welldeveloped theories about the function and purpose of sex. Even Linnaeus's system of classifying plants solely by the number of stamens and pistils-a quantitative procedure bearing no relation to the affinities and characteristics of groups of plants found in nature-emphasized the universal necessity of sexual reproduction. Linnaeus gave a primacy to plant sexuality that no naturalist had attempted before, and thus the fate of his classification scheme was seen to hinge on the fate of ideas about plant sexes. In short, to be a Linnaean taxonomist was to believe in the sex life of flowers.

The point did not pass unnoticed among Linnaeus's critics, and anti-Linnaeans jostled to demonstrate that the sexuality of plants was nonsense. Lazzaro Spallanzani took the lead and was quick to attack Linnaeus's observations on fecundation, claiming that productive seeds were born in gourds, spinach, and hemp without any pollination-a claim going right to the heart of the doctrine of sexuality and casting doubt on the universality of Linnaeus's scheme. ${ }^{17}$ From France other naturalists such as Charles Bonnet and John Turbeville Needham disputed Linnaeus's claims about the way pollen acted in fertilization. Further attacks came from Michel Adanson, who wrote his Famille des plantes (1763-1764) to counter Linnaeus's exclusive emphasis on sex and the number of sexual organs. Adanson considered that classification schemes should be based only on natural groupings of plants and animals as discerned by anatomical resemblances. Linnaeus, he felt, had sacrificed such aims and beliefs for the sake of expediency:

\footnotetext{
${ }^{12}$ Carolus Linnaeus, Disquisitio de quaestione ab Academia Imperiali Scientiarum Petropol . . . Sexum plantarum argumentis et experimentis novis, \&c. (St. Petersburg, 1760).

${ }^{13}$ Carolus Linnaeus, Classes plantarum, seu systemata plantarum omnia a fructificatione desumpta ... (Leiden, 1738), p. 441: "A flower is nothing but an act of the generation of plants" (my translation).

${ }^{14}$ Linnaeus, Sexes of plants (cit. n. 11), p. 56: "A genus is nothing else than a number of plants sprung from the same mother by different fathers."

15 Ibid., pp. 13-28.

16 J. L. Larson, Reason and Experience: The Representation of Natural Order in the Work of Carl von Linné (Berkeley/Los Angeles: Univ. California Press, 1971). See $\varepsilon \rightarrow$ Larson, "Linnaeus and the Natural Method," Isis, 1967, 58:304-320.

${ }_{17}$ Lazzaro Spallanzani, Dissertazione di fisica animale e vegetabile, 2 vols. (Modena, 1780), Vol. II. See also Delaporte, Nature's Second Kingdom (cit. n. 7), pp. 118-119; J. E. Smith, in his trans. of Sexes of Plants (cit. n. 11), criticized Spallanzani's attack on Linnaeus's doctrine of sexuality, pp. x, $43-44 n$.
} 
his numerical system, though quick and easy, frequently brought together disparate plants and separated similar ones, and was therefore thought to be "artificial" rather than "natural." In yet another arena, the most daring and dangerous of the philosophes, Julien Offray de La Mettrie, poked fun at the terminology of the sexual system in a little book circulated in fashionable Parisian society which depicted the flower parts in graphic humanized parody, a single stamen representing the penis, and so forth. Meanwhile Buffon volleyed from the philosophical corner, arguing that there was no need for-and no merit in-Linnaeus's pronounced artificiality. In Britain the francophiles Charles Alston and William Smellie also found effective anti-Linnaean propaganda in the sexual innuendos that could so easily be drawn out of the numerical system, with Alston taking a high moral tone and spluttering in outraged propriety, and Smellie asserting that Linnaeus had pushed analogy beyond all decent limits, so that it became truly ridiculous. ${ }^{18}$

Stung into action, a strong coterie of English botanists struck back with a flurry of translations and catalogues heralding Linnaeus as the prince of flowers. Although Basil Soulsby and Frans Stafleu have admirably described the work of these first disciples of Linnaeus, particularly in Britain, there are several names that bear repetition here. John Berkenhout, though not the earliest translator of Linnaeus by any means, reached a wide audience with his little Clavis anglica linguae botanicae (1764). James Lee was perhaps even more widely known through the many editions of his Introduction to Botany (1760). Hugh Rose translated Linnaeus's Philosophia botanica in 1775, and William Curtis presented "Linnaeus's system of botany" to English readers in 1777. James Edward Smith, later to become the most famous Linnaean of them all through his purchase of Linnaeus's collections and manuscripts and the foundation, in 1788, of the Linnean Society of London, translated Linnaeus's Reflections on the Study of Nature and then the controversial prizewinning essay on the sexes of plants. British readers had never been subjected to so many expository texts before; British botanists never so anxious to defend the work of their master. ${ }^{19}$

${ }^{18}$ Michel Adanson, Familles des Plantes, 2 vols. (Paris, 1763), discussed at length in Jean-Paul Nicolas et al., Adanson: The Bicentennial of Michel Adanson's "Familles des plantes," 2 vols. (Hunt Monograph Series, 1) (Pittsburgh: The Hunt Botanical Library, 1963); Julien Offray de La Mettrie, L'homme plante (Paris, 1748), ed. Francis Rougier (New York: Columbia Univ. Press, 1936); John Lyon and Phillip Sloan, eds., From Natural History to the History of Nature: Readings from Buffon and His Critics (Notre Dame, Ind.: Univ. Notre Dame Press, 1981), pp. 97-128; Charles Alston, $A$ Dissertation on Botany (London, 1754), pp. 42-71 (see also Ritterbush, Overtures to Biology [cit. n. 7], p. 119); and William Smellie, The Philosophy of Natural History, 2 vols. (Edinburgh, 1790-1799), Vol. I, p. 248.

19 Basil H. Soulsby, A Catalogue of the Works of Linnaeus, and Publications More Immediately Relating Thereto ..., 2nd ed. (London: British Museum [Natural History], 1933); Frans A. Stafleu, Linnaeus and the Linnaeans: The Spreading of Their Ideas in Systematic Botany, 1735-1789 (Regnum Vegetabile, 79) (Utrecht: International Association for Plant Taxonomy, 1971); John Berkenhout, Clavis anglica linguae botanicae; or, a Botanical Lexicon; in Which the Terms of Botany, Particularly Those Occurring in the Works of Linnaeus, and Other Modern Writers, are Applied, Derived, Explained, Contrasted, and Exemplified (London, 1764), a work undoubtedly owned by Erasmus Darwin, since there is a copy in the Cambridge Univ. Library once in the possession of his son Robert Waring Darwin and thence passed on to his grandson Charles Robert Darwin; James Lee, An Introduction to Botany: Containing an Explanation of the Theory of that Science, and an Interpretation of Its Technical Terms (London, 1760); The Elements of Botany . . . Being a Translation of the "Philosophia botanica," and Other Treatises of the Celebrated Linnaeus, trans. Hugh Rose (London, 1775); William Curtis, Linnaeus's System of Botany, So Far as Relates to His Classes and Orders of Plants (London, 1777); Andrew Thomas Gage, A History of the Linnean Society of London (London: Linnean Society of London, 1938); James Edward Smith, Memoir and Correspondence . . . , 
Among them was Erasmus Darwin, busy in the affairs of a new botanical society in Lichfield and tending his own botanic garden a mile or so outside the city limits. In the company of two other friends, Darwin established the grandly titled Botanical Society of Lichfield, a society that never had more than the three original members and that was created entirely in order to translate into English Linnaeus's Species plantarum and the slightly later volume, the Genera plantarum. ${ }^{20}$ Both books were seen as essential weapons in the defense of Linnaean taxonomy, as indicated by the enthusiasm with which eminent London figures like Sir Joseph Banks and conspicuous Linnaeans like Jonas Dryander encouraged Darwin, writing on the Botanical Society's behalf, to persevere with his efforts. $^{21}$ Banks was especially gracious, helping Darwin and his botanical colleagues acquire copies of the best taxonomic catalogues and discreetly criticizing other systematic works. To Banks, the translations filled a gap in the anglicization of Linnaeus, which contemporary "introductions" and "explanations" had left embarrassingly open. Banks, who had taken Daniel Solander, Linnaeus's star pupil, round the world to Australia and back, had invested much of his scientific reputation in the Linnaean arrangement of his own outstanding herbarium in London. ${ }^{22}$ His encouragement and endorsement of Darwin's work, while probably serving his own purposes, were nevertheless gratefully acknowledged by Darwin, who subsequently dedicated the first translation to the great man of Soho Square.

\section{DARWIN'S LANGUAGE OF FLOWERS}

Darwin's translations of Linnaeus's catalogues were capable and plain-spoken, taking their tone from the decidedly blunt originals. Linnaeus had minced no words when he described male and female forms in plants, nor did Darwin-unlike his contemporary William Withering, who was concerned that his own botanical book not include any of Linnaeus's improper words and invented euphemisms such as "chives" and "pointals" for stamens and pistils, themselves only words of Latin and Greek origin meaning threads and columns. ${ }^{23}$ Darwin on the

ed. Lady Smith, 2 vols. (London, 1832); and Smith's translations, Reflections on the Study of Nature: Translated from the Latin of the Celebrated Linnaeus (London, 1785), and Sexes of Plants (cit. n. 11).

${ }^{20}$ Botanical Society of Lichfield, A System of Vegetables, According to Their Classes, Orders, Genera, Species, with Their Characters and Differences . . . translated from the 13th Edition of the Systema vegetabilium . . . and from the Supplementum plantarum of the Present Professor Linnaeus, 2 vols. (Lichfield, 1783); and Botanical Society, The Families of Plants, with Their Natural Characters . . . Translated from . . . the Genera plantarum of . . . Linnaeus (Lichfield, 1787). On the Botanical Society see also Letters of Erasmus Darwin, pp. 109-111. Although there is little direct evidence beyond a few letters, it seems clear that Erasmus Darwin was the sole author of these catalogues. Yet Darwin always referred to the translations as the joint activity of the Botanical Society and the title pages of both books name only the society as author. Few contemporaries would have attributed them to Darwin alone.

${ }^{21}$ Letters of Erasmus Darwin, pp. 112-120.

22 Stafleu, Linnaeus and the Linnaeans (cit. n. 19), pp. 199-240; and Patrick O'Brian, Joseph Banks: A Life (London: Collins Harvill, 1987). See also D. J. Mabberley, Jupiter Botanicus: Robert Brown of the British Museum (London: British Museum [Natural History]; Brunswick: J. Cramer, 1985).

${ }^{23}$ Letters of Erasmus Darwin, pp. 74-75; and William Withering, A Botanical Arrangement of All the Vegetables Naturally Growing in Great Britain (Birmingham, 1776). Withering's concern was reiterated by Curtis, Linnaeus's System (cit. n. 19), p. 2: "One chief aim in this translation, has been to convey to the English reader the Author's explanation of his system in terms the least exceptionable." 
other hand, like James Lee, John Berkenhout, and even his brother Robert Waring Darwin, who had all published before him, ${ }^{24}$ called them males and females, husbands and wives (see Figs. 1 and 2).

It is worth emphasizing here that it was Linnaeus who initiated this personification of the sexual relations of plants and that his more robust followers were merely accepting and extending the practice into English-language works. This use of personification allowed Linnaeus to write of plant sexuality as a "marriage" and the male and female organs as "husbands" and "wives"; he wrote of the petals (corolla) as the "marriage bed"; and he discussed the existence of monoecious and dioecious plants in terms of one or two different "houses." By coining the words monoecious and dioecious (derived from the Greek for one or two homes or houses), Linnaeus set up a system of metaphors through which plant sexuality could be made intelligible by being modeled on human society, in much the same way as La Fontaine's moral fables owed their dramatic force and piquancy to their location in the animal world rather than the human. Many translators saw the value of such metaphors. In The Elements of Botany (his translation of Linnaeus's Philosophia botanica), for example, Hugh Rose wrote: "The calyx then is the marriage bed, the corolla the curtains, the filaments the spermatic vessels, the antherae the testicles, the dust the male sperm, the stigma the extremity of the female organ, the style the vagina, the germen the ovary, the pericarpium the ovary impregnated, the seeds the ovula or eggs."25

However, Darwin ventured much further than Linnaeus in the bravura with which he maintained a policy of plain speaking in the translations. He believed that the English language had greater expressivity than Latin, and he consciously attempted to use English to display the inner meanings of Linnaeus's terms. In this he had, for a short while at least, the advice of the celebrated Samuel Johnson, also once resident in Lichfield. ${ }^{26}$ Darwin spelled out his views in the preface to the Botanical Society's first translation: "The learned reader will perceive, that we have made a slight change in the construction of the sexual distinctions of the Classes on account of the greater delicacy of modern language; hence the words one male, and one female, are used in preference to one virility and one feminality." 27 In later years he referred to the Botanical Society's translations as having "rendered that translation of Linnaeus as expressive and as concise, perhaps more so, than the original." 28 In order to maintain such expression, Darwin went so far as to coin more than fifty new botanical words-for example, "stipule" for a lateral appendage often resembling a small leaf or scale ${ }^{29}$-and introduced a set of terms to describe the various physical juxtapositions of stamens,

${ }^{24}$ Lee, Introduction to Botany, pp. 10-11, 72-73; Berkenhout, Clavis anglica (both cit. n. 19); and Robert Waring Darwin, Principia botanica: Or, a Concise and Easy Introduction to the Sexual Botany of Linnaeus (Newark, 1787).

${ }^{25}$ Linnaeus, Elements of Botany, trans. Rose (cit. n. 19), p. 151.

${ }^{26}$ Letters of Erasmus Darwin, pp. 114, 172.

${ }^{27}$ Botanical Society of Lichfield, System of Vegetables, Vol. 1, p. v. The same sentiment is echoed in the society's Families of Plants, p. v: "The conciseness, the perspicuity, and the spirit of our author live, we hope, undiminished by the change of language." (Both cit. n. 20.)

${ }^{28}$ Darwin, Loves of the Plants, p. 130.

$\rightarrow$ Desmond King-Hele, "Erasmus Darwin, Man of Ideas and Inventor of Words," Notes and Records of the Royal Society of London, 1988, 42:149-180. Darwin's interest in language was further expressed in philosophical notes to the Temple of Nature (London, 1803), pp. 93-106, entitled "The Theory and Structure of Language." 
CHARACTERS OF CLASSES.
I. ONE MALE.
One hufband in marriage.
One famen in an bermapbrodite fiower.
II. TWO MALES.
Two hubands in the fame inarriage.
III. THREE MALES.
Three hufbands in tice fame marriage.
Three famens in an bermaphrodite finver.
IV. FOUR MAL.ES
Four hurbands in the fame marriage.
Four famens in the fame flower with the fruit.
V. FIVE.MALES
Five hubbands in the fame marriage,
Five flamens in an bermapbrodite flower.
VI. SIX MALES.
Six hufbands in the fame marriage.
Six flamens in an hermapbrodite flower.
VII. SEV EN MALES.
Seven hurbands in the fame marriage.
Seven hurbands in the fame marriage.
Siven flamens in the fame fower with the piftil.
VIII. EIGHT MALES.
Eight hubands in the fame marriage.
IX. NINE MALES.
Eight famens in the fame flower with the pillil.
Nine hurbands in the fame marriage.
Nine Ramens in an hermapbrodite flower.
X. TEN MALES.
Ten hubands in the fame marriage.
Ten flamens in an bermaphrodite flower.
XI. TWELVE MALES.
Twelve hufbands in the fame marriage.
Twelve famens to nineteen in an bermaphrodite fowier.
XII. TWENTY MALES
Generally twenty hufbands, often more.
Stamens inferted on the calyx (nut on the receptacle) in an bernapbroditc flower.

Figure 2. Darwin's translation of the chief characteristics of Linnaeus's twenty-four taxonomic classes, as given in The Families of Plants, pages Ixxviii-Ixxix. Reproduced by permission of the Syndics of the Cambridge University Library.

such as "confederate males," which are joined together at the base, or "brotherhoods," which mature in sets of three or five at different times in the life of the flower. Terms such as these may well have inspired further metaphors or trains of thought that eventually came together in his later botanical verses.

\section{THE LOVES OF THE PLANTS}

A close friend and confidante of Darwin's was the poetess Anna Seward, known to many as "The Swan of Lichfield" and at this time celebrated for her Elegy on Captain Cook (1780) and for a critical account of George Washington in her Monody on Major André (1781). Seward, who helped Darwin tend his botanic garden, encouraged him to turn his talent for light verse toward plants by presenting him with a short poem on the nymphs and gnomes in his Lichfield garden. Darwin, never averse to nymphs and goblins in his poetry as well as in his garden, thought that "the Linnean System is unexplored poetic ground, and an happy subject for the muse. It affords fine scope for poetic landscape; it suggests metamorphoses of the Ovidian kind, though reversed." 30

Darwin wrote the bulk of The Loves of the Plants concurrently with the Botanical Society translations of Linnaeus. The poem, published in 1789, was begun

${ }^{30}$ Anna Seward, Memoirs of the Life of Dr. Darwin, Chiefly during His Residence at Lichfield; with Anecdotes of His Friends and Criticisms on His Writings (London, 1804), on pp. 125-131, quoting Darwin on pp. 130-131. Seward's verses, slightly altered by Darwin, were published as the "Exordium" to Loves of the Plants. 
in 1779, and the two translations were issued in 1783 and 1787. There is a strong possibility that he intended The Loves of the Plants to be a reaffirmation of Linnaeus's insistence on plant sexuality in the face of increasingly numerous anti-Linnaean publications. Furthermore, it seems likely that the poem also represents a mild amendment of Linnaeus's ruling about the number of organs alone being the crucial factor. Darwin's personification of the stamens and pistils can in itself be seen as an attempt to introduce a real, physiological element into a highly abstract scheme; but he went further by also stressing the proportion, length, and arrangement of the organs within Linnaeus's numerical system. Darwin believed that the length of the male filaments or of the female style had a marked effect on the process of fertilization. Other botanists had demonstrated the way in which stamens bend over the stigma to pollinate it, some stamens even moving in turns, bending and retreating. Equally, the pistil in some plants bends to a set of stamens, and other pistils do not develop fully until the first has retreated.

Darwin emphasized these behavioral traits in his verses by accurately representing both the structure of each plant and its individual means of fertilization. He wrote of relative positions, of males and females bending to embrace each other, of sets of brothers, of knights and their squires, and so on. Melissa, the lemon balm, was defined just as much by its reproductive actions as by its structure:

Two knights before thy fragrant alter bend,

Adored Melissa! and two squires attend. ${ }^{31}$

The alpine flower Draba received much the same treatment from "four rival Lords" while "two menial youths attend," a comment on the differing maturation rates of the various stamens. ${ }^{32}$ Later on, in his botanical book the Phytologia, published in 1800, Darwin set out this belief in the importance of the relative proportions and situations of the stamens, hoping to improve a little on Linnaeus's system while still expressing his sincere opinion that the numerical, sexual approach was unrivaled among taxonomies ${ }^{33}$ So the personification of stamens and pistils was perhaps Darwin's way of putting some organic functioning back into Linnaeus's artificial constructs, without conceding the game to French and British proponents of natural classification.

He had other aims as well, aims that were equally efficiently served by the sexual arrangements of flowers and the motif of human love and that were not so far removed from those attributed to Linnaeus. These aims, though apparently only nascent in Darwin's thoughts during the 1780s, soon emerged in his long poem The Economy of Vegetation and were thence elaborated in other books and writings, particularly the Zoonomia and Phytologia. Darwin wanted to demonstrate the fecundity of the natural world and to present his thesis that sexual

\footnotetext{
${ }^{31}$ Darwin, Loves of the Plants, canto 1, lines 59-60 (p. 6). All references are to the first (1789) edition, since Darwin added and altered later editions. Unfortunately, the printer made several mistakes in the line numbers (particularly in canto 1, lines 250-300). Line numbers are therefore followed by page references to the first edition.

32 Ibid., canto 1, lines 219-222 (p. 22).

${ }^{33}$ Erasmus Darwin, Phytologia; or the Philosophy of Agriculture and Gardening: With the Theory of Draining Morasses, and with an Improved Construction of the Drill Plough (London, 1800), pp. 564-578.
} 
reproduction is the "chef d'oeuvre, the masterpiece of nature." 34 Nothing in nature could exist, he thought, without reproduction, and the purpose of existence was to reproduce. Central to this argument, as Roy Porter has recently emphasized, was Darwin's belief that sexual reproduction was the hidden force behind evolution and progress, since new organisms were introduced into the world through variations that arose in the offspring of sexual unions alone. ${ }^{35}$

Like others before him, Darwin was unsure exactly how variation came about or how much or what each parent might contribute to their progeny, but he seems to have held the view that both parents were involved and that the inherent irritability of living matter and the association of ideas led to adaptive responses in the embryo. However, it is difficult to know precisely what Darwin thought at the time he was writing The Loves of the Plants. In the first edition of his Zoonomia (1794-1796) he suggested that the male partner alone carried the formative influence, a view subsequently changed in favor of both partners in the Phytologia and the third edition (1801) of the Zoonomia. ${ }^{36}$ In this later view, males and females provided different, complementary materials, a suggestion Darwin culled from Linnaeus's doctrine of plant reproduction, and individual variations were produced by a rearrangement of different quantities of the respective parental molecules or contributions. ${ }^{37}$ Out of these individual differences there emerged a chain-or continuity-of forms, seen by Darwin as an evolutionary scale of nature progressing from the simplest to the most complex of living organisms.

He included plants in this evolutionary chain of being and applied his arguments about sexual reproduction to them with as much gusto as he did for the animal kingdom. Plants were given the attributes of sensation, movement, and a certain degree of mental activity, in order to provide a continuous scale between the lowest, simplest forms of living beings and the highest. ${ }^{38}$ They possessed the same four classes of bodily actions itemized in the Zoonomia, that is, the properties of irritation, sensation, volition, and association, although to be sure Darwin

34 Darwin, Zoonomia (cit. n. 5), Vol. I, p. 514; Darwin, Phytologia, p. 114; and Darwin, Temple of Nature (cit. n. 29), p. 36. The term masterpiece had more meanings than the obvious here; for cultured people in the eighteenth century the word was a euphemism for vagina, a hidden allusion that certainly reinforced Darwin's general meaning. See Peter Fryer, Mrs. Grundy: Studies in English Prudery (London: Dennis Dobson, 1963), p. 48.

${ }^{35}$ Darwin, Phytologia (cit. n. 33), p. 115: "But from the sexual, or amatorial generation of plants new varieties, or improvements, are frequently obtained"; see Roy Porter, "Erasmus Darwin: Doctor of Evolution?" in History, Humanity and Evolution: Essays for John Greene, ed. James R. Moore (Cambridge: Cambridge Univ. Press, 1989).

${ }^{36}$ King-Hele, Doctor of Revolution (cit. n. 2), p. 283; and Darwin, Zoonomia (cit. n. 5), Vol. I, pp. 478-533. See also ibid., 3rd ed., 4 vols. (London, 1801), Vol. II, pp. 277-304. It was apparently Darwin's studies of the reproductive mechanisms of plants that led him to change his opinion: ibid., Vol. II, p. 277.

${ }^{37}$ Darwin, Phytologia, pp. 91-131, esp. pp. 127-129, in which male organs are held to secrete fibrils or molecules with "formative" or "nutritive appetencies" and female organs secrete "formative" or "nutritive propensities." These mingle together, making an individual "resembling in some parts the form of the father, and in other parts the form of the mother, according to the quantity or activity of the fibrils or molecules at the time of their conjunction" (p. 130).

${ }^{38}$ Darwin, Zoonomia (cit. n. 5), Vol. I, pp. 101-107. Even in his earliest botanical writings, Darwin had ascribed such attributes to plants. In the Botanical Society of Lichfield Families of Plants, p. xix, he wrote, "For vegetables are, in truth, an inferior order of animals, connected to the lower tribes of insects, by many marine productions, whose faculties of motion and sensation are scarcely superior to those of the petals of many flowers, or to the leaves of the sensitive plant, the moving plant, and the Fly trap." See also Ritterbush, Overtures to Biology; and Delaporte, Nature's Second Kingdom (both cit. n. 7). 
agreed that these were displayed to a lesser degree than in animals or humans. ${ }^{39}$ Plants too indulged in the pursuit of pleasure and the avoidance of pain; they too sought gratification through sexual reproduction. Darwin's Phytologia, his subsequent paean to the vegetable kingdom, is crammed with examples of sensate plants, plants that move, plants that feel, plants that think or, at the very least, can tell the time of day. Sadly neglected by historians, this botanical text takes up all the themes we traditionally associate with the Zoonomia and the evolutionary poems, but applied by Darwin to plants in order to bring them fully into a comprehensive philosophy of nature.

The Loves of the Plants, then, may be seen as an early study in what was to be Darwin's lifelong commitment to the idea of transmutation. It was important for him to show plants as an integral part of animate nature, as organisms with the same attributes as animals in a degree appropriate to their place in the scale of organization, and important to show them as sexual beings able to contribute to the variability and progress of the natural world. His first public expression of these interests therefore took the form of identifying himself as a Linnaean who believed in the sexuality of plants. This was to be carried out by a sustained application of the simple metaphorical device of seeing plants as people.

\section{THE IDEA OF A BOTANIC GARDEN}

The Loves of the Plants has long been acknowledged as an extended didactic analogy between plants and humans; not wonderful poetry, by any means, but as Desmond King-Hele puts it, full of "glittering couplets" that led Wordsworth in his youth to write of the "dazzling manner of Darwin." 40 Samuel Taylor Coleridge, who famously condemned Darwin's extravagant diction ("I absolutely nauseate Darwin's poem" he wrote in 1796), dryly admitted that he had at least "accumulated and applied all the sonorous and handsome-looking words in our language." ${ }^{41}$ Historians of science, accustomed to finding serious meaning only in Darwin's other poems and longer prose works, might justifiably ask how far the glitter and dazzle of The Loves of the Plants served merely to satisfy the usual requirements of story, meter, and rhyme. But a closer examination of the structure of Darwin's poem and the metaphorical framework shows that its author had several conscious aims that could best be expressed through this deliberately chosen vehicle.

The poem, which takes the form of a narrative delivered by a "Botanic Muse" who is described as having formerly guided Linnaeus, is loosely arranged to reflect the passing hours of a single day. After some prefatory advice from the author and others on what follows, the verses are divided into four cantos, each canto opened and closed by the narrator calling her nymphs back to her side, interspersed with dialogues between the poet and his bookseller about the metaphysics and characteristics of poetry. Beyond this, the verses have little narrative thread. Each plant, described as if it were a group of human beings according to the number of stamens and pistils it possesses, is presented in an anecdote designed to amuse the assembled nymphs as they dally in an Arcadian landscape (see Fig. 3).

${ }^{39}$ Darwin, Zoonomia, Vol. I, pp. 37-53.

${ }^{40}$ King-Hele, Romantic Poets (cit. n. 2), pp. 67-68.

${ }^{41}$ Ibid., p. 136. 
The setting is clearly a botanic garden in which exotic species intermingle with indigenous plants. For Darwin, as for other members of the intellectual leisured classes, reference to a botanic garden evoked a constellation of ideas and emotions that combined scientific purpose with recreational pleasure. Gardens glorified both the practical expertise of horticulturists and the serious activities of taxonomists and medical personnel. National pride was reflected in the breadth and variety of such collections, each plant representing geographical explorations in the past and the nation's political allegiances and commercial intentions. Gardens were also obvious repositories of "nature," a display of plants outside their usual geographic boundaries conjuring up notions of an untrammeled, fecund

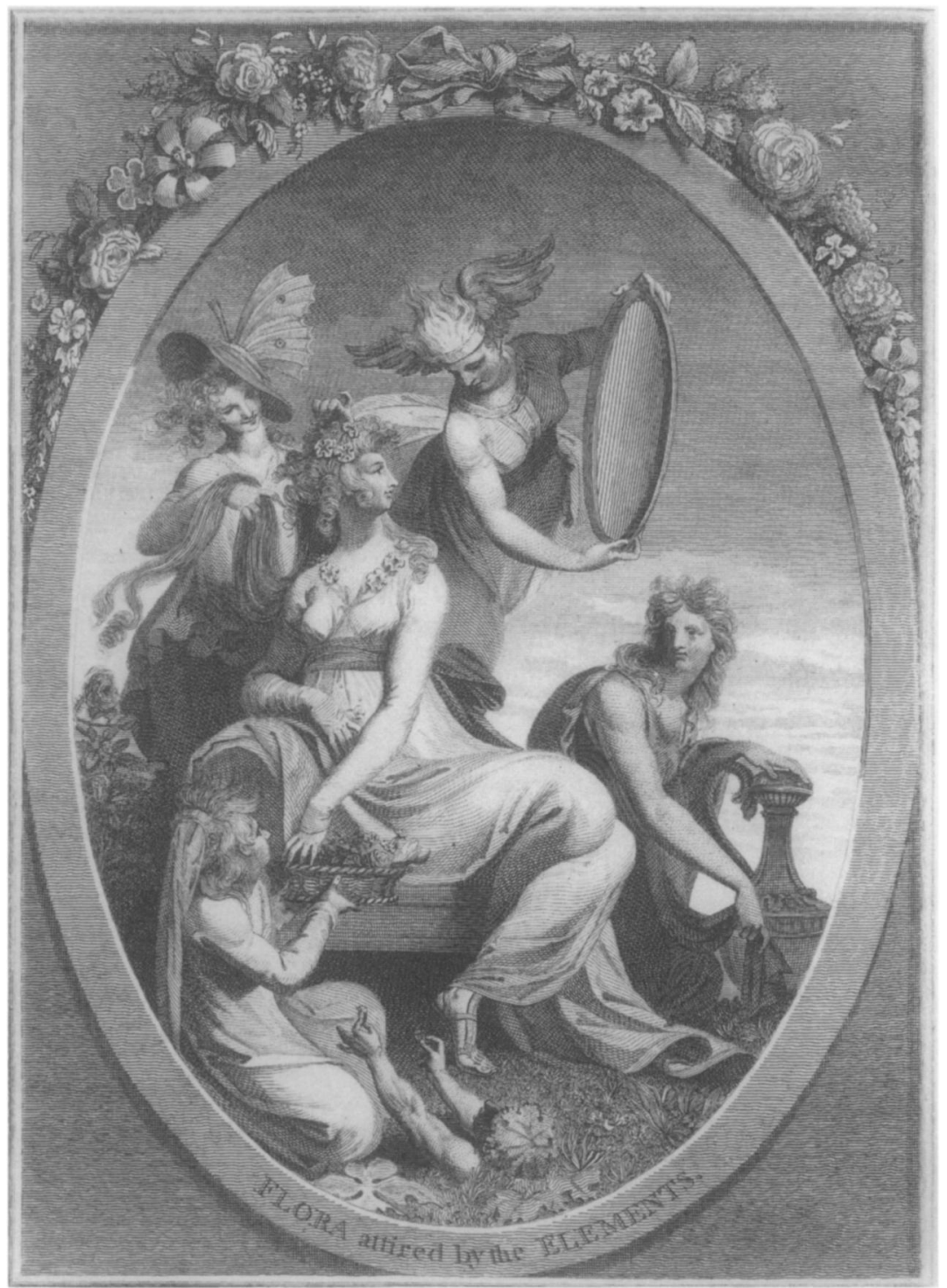

Figure 3. "Flora attired by the Elements," designed by Henry Fuseli and engraved by Anker Smith, 1791. The frontispiece to Erasmus Darwin, The Economy of Vegetation, Part I of The Botanic Garden (London, 1792). Reproduced courtesy of the Wellcome Institute Library. 
world-for some people almost literally a "garden of Eden," for others representative of organisms living in a state somehow beyond or outside the conventional limits and laws of nature. ${ }^{42}$ Considerations like these were easily generalizable to the social and even the political world, should an author wish to do so. In Darwin's case it seems highly probable that he intended to make full use of this particular set of associated images. The motif of a botanic garden served to indicate that his verses dealt with plant species and their human analogues as if they were temporarily free of the usual constraints of the ordinary world.

But Darwin did not depend on these indefinable evocations alone. The structure of his poem was also closely tied to the idea of a botanic garden. As in a real botanic garden, the species were arranged or disposed according to their taxonomy or their useful attributes. Darwin deftly manipulated this metaphor to allow himself to group together species of plants that do not necessarily follow each other in strict botanical order, as in his canto 3 (on medicinal plants), and to give himself room to ignore other, less poetic, plants that would overload his delicate confection. He also capitalized on the chance to juxtapose extravagant imagery, appropriate to tropical exotics, with gentler, more pastoral allusions, providing the variety and ingenuity that his contemporaries would have expected and in which he came to excel. The poem's "garden" is full of profusion and confusion, all artfully ordered and cultivated by a knowing eye to give the impression of unadulterated nature, an impression central to eighteenth-century ideas about the picturesque and an integral element in the way in which Darwin and other gentlefolk thought about the natural world. ${ }^{43}$ Darwin gave depth to the imagery here with the revelation that the garden loosely described in the poem was none other than his own in Lichfield, carefully laid out by himself, here translated from a form intended to delight the visual senses into the medium of poetry.

Thus the idea of a botanic garden in which to set the amours of flowers can be seen to be far more than a simple trope: it served as an organizing principle and as structure and metaphor. In addition, the botanic garden of the poem was a real garden in Lichfield, the poet's personal creation. The pictures painted by Darwin therefore possess meanings that went beyond the surface of the "gorgeous diction" that Coleridge so decried.

Darwin described only eighty-three species out of the many hundreds catalogued by Linnaeus. Each description included the numbers of stamens and pistils, in accordance with the Linnaean system, and ten or more lines of metaphorical, allusive poetry closely based on the appearance of the plant or its known attributes: for example, the grapevine is shown as a clinging, twining female; the poppy as a queen of sleep; the foxglove as a healing goddess bringing the drug digitalis; and so on. Lengthy footnotes, as in all Darwin's poems, explained these allusions. Other personifications took their cue from classical learning, though reversing the usual human-to-plant metamorphosis of classical myth. Linnaeus, like others before him, had laid great weight on the actual name of a plant or

\footnotetext{
${ }^{42}$ See esp. John Prest, The Garden of Eden: The Botanic Garden and the Re-Creation of Paradise (New Haven, Conn.: Yale Univ. Press, 1981, 1988).

${ }^{43}$ See McNeil, "Scientific Muse" (cit. n. 3), pp. 183-190; and Keith Thomas, Man and the Natural World: Changing Attitudes in England, 1500-1800 (London: Allen Lane, 1983). Darwin's emphasis on an epistemology governed by the visual sense was partly based on his son's work. See Charles Robert Darwin, "On Ocular Spectra," in E. Darwin, Zoonomia (cit. n. 5), Vol. I, pp. 534-566; and E. Darwin, Loves of the Plants, pp. 128-129.
} 
animal, stipulating that it should define the taxonomic relationships of the species and in a more traditional sense "encapsulate" the very essence of the species. He perceived the activity of naming as akin to religious baptism, almost as if the organism was not part of the Christian world until it possessed its own particular species name. ${ }^{44}$ To a large extent, Linnaeus's nomenclature therefore reflected the ancient myths that had emerged around each species. ${ }^{45}$ Erasmus Darwin, naturally enough, used the Linnaean names freely in his verses. More often than not, the classical allusions enshrined in Linnaeus's names were the motif on which Darwin's personifications were embroidered. These needed no explanation in the world of the classically educated eighteenth-century reader, and even women, Darwin's intended readers, who rarely had any formal training in ancient literature, would have been familiar with the gods and goddesses mentioned by Darwin.

Out of this rich mixture of allusions one tendency emerges clearly. Although Darwin was interested in describing accurately the reproductive structures and habits of plants, his poem focused largely on the sexual and social behavior of women. The characterizations of men and women were carefully matched to create an appropriate anecdote that would explain and define each chosen species; yet Darwin's efforts seem primarily directed toward creating a vivid picture of the women invoked in his verses: he gave the plant-women the central role in characterizing the behavior or story of each partnership, and the female personalities were allowed to carry the tone and impact of each stanza. The men-the stamens of Linnaeus's scheme-were not given the same attention or depth of characterization, even in some cases being sketched solely in terms of almost empty labels such as "swain" or "beau." In some sense this is a reversal of Linnaeus's system, in which the stamens-the males-defined the primary groups of plants (taxonomic classes) and could therefore be said to be more significant than the pistils, the females, which are merely secondary taxonomically (see Fig. 1). But Erasmus Darwin favored the idea of females taking a substantial part in reproduction, contributing actual molecules for the medulla of the offspring, not just a nutritive location for the growth of preformed seeds (although, as already mentioned, he did at a later stage question this interpretation in the first edition of the Zoonomia). In part, Darwin's literary sensibilities, in common with those of others of the same generation, whose taste was formed by the works of Fielding, Defoe, and Richardson, encouraged him to cast the poem essentially in terms of what women did and did not do. One hint given by Desmond King-Hele in his edition of Darwin's letters is also relevant here, that by 1778 Darwin was in love with Elizabeth Pole, the wife of another local resident. ${ }^{46}$ The Loves of the Plants, begun in 1779 and composed intermittently

44 Janet Browne, "Botany and Botanists," an essay review of E. L. Greene, Landmarks of Botanical History, ed. F. N. Egerton; and Linnaeus: The Man and His Work, ed. Tore Frängsmyr, Hist. Sci., 1984, 22:207-209.

$\rightarrow$ John L. Heller, "Classical Poetry in the Systema naturae of Linnaeus," Transactions of the Proceedings of the American Philological Association, 1971, 102:183-216. Even in manuscript notes Linnaeus framed his identifications in terms of classical allusions: next to his written description of the species Andromeda, he drew a sketch of the girl Andromeda, chained to a rock with a dragon at her feet as in the Greek myth, juxtaposed with a hand-drawn picture of the plant itself. MS Lachesis Lapponica, fol. 87, Linnean Society, London.

${ }^{46}$ King-Hele, in Letters of Erasmus Darwin, pp. 76-78; and Henry Nidecker, "The Poetical Prelude of Erasmus Darwin's Second Marriage," in Festschrift Gustav Binz . . . zum 70. Geburtstag am 
during the following decade, may at first have been intended as a kind of love song to Elizabeth Pole, hence Darwin's emphasis on women as the arbiters of masculine behavior. As luck would have it, Mrs. Pole was soon a widow and free to marry Darwin in 1781.

\section{THE PERSONIFICATION OF PLANTS}

Table 1 presents a synopsis of Darwin's poetic imagery relating to women and their sexual relations with men, ranged against the number of stamens and pistils as stipulated in Linnaeus's classification of plants. Putting it another way around, we can say that the table lists what might be called the "facts" of nature (the number of stamens and pistils) in conjunction with the social moral or metaphor that Darwin draws out of these "facts" when viewed in a human context. The characterizations in the table are necessarily brief but serve, it is hoped, to present an accurate version of each botanical image. Darwin's words have been used whenever possible and the key ideas checked against Darwin's own index, which was provided in a "Catalogue of the Poetic Exhibition" at the end of The Loves of the Plants for those who might have missed the point of his metaphors.

For clarity, the table has been divided into sections according to the relative number of stamens and pistils. In the first section there are fourteen anecdotes based on the sexual relationships of plants with one stamen and one pistil (one man and one woman). In this section the table follows Darwin and Linnaeus by including the Cryptogamia as sexually reproducing organisms that-as the name given to them by Linnaeus indicates-hide their activities from the eyes of naturalists. The Cryptogamia are marked by an asterisk in the table.

Otherwise, the number of plants with only one stamen and one pistil is very small. The vast majority possess five stamens and one pistil, although another biological quirk affects the figures slightly. Often the stamens are fused together in a tube, or the florets, male and female alike, are reduced in size and clustered together to make up a single flower head, as in the chrysanthemum, sunflower, or daisy-classed together by Linnaeus as the Polygamia. The table again follows Darwin's understanding of the scheme by including these in the section with five males and one female. When the numbers of males and females are both greater than one, they are given as Darwin presented them and not reduced to their lowest common denominator, since Darwin had different things to say about ratios of, for example, ten-to-ten from those he said of one-to-one.

Darwin himself took considerable artistic license and made use of only the more interesting or appropriate plants for his purposes. He followed Linnaeus's outline and gave at least one example of each of his classes and orders, though not necessarily in strict taxonomic series, as, for example, in the third canto, where he deals with medicinal and other useful plants together. In the table,

16 Januar 1935 von Freunden und Fachgenossen dargebracht (Basel: Benno Schwabe, 1935). The inference that Loves of the Plants was partly written with Elizabeth Pole in mind is wholly mine but is based on a poem of Darwin's addressed to her in 1775, in which Darwin, thinly disguised as a wood nymph from his botanic garden, begs that she should not proceed to lop any more trees in that garden. Certainly the garden metaphor played a significant role in their courtship, and Loves of the Plants was composed during the first years of their marriage. Together they raised a large second family, which cheerfully incorporated Darwin's two remaining sons from his first marriage and two natural daughters, Mary and Susan Parker, by another woman. See E. Posner, "Erasmus Darwin and the Sisters Parker," History of Medicine, 1975, 6(pt. 2):39-43. 
Table 1. Images of women in The Loves of the Plants

\begin{tabular}{ccc}
\hline $\begin{array}{c}\text { No. of } \\
\text { males } \\
\text { (stamens) }\end{array}$ & $\begin{array}{c}\text { No. of } \\
\text { females } \\
\text { (pistils) }\end{array}$ & Image \\
\hline
\end{tabular}

I. One male and one female

\begin{tabular}{|c|c|c|}
\hline 1 & 1 & A virtuous, timorous beauty (Canna, 1:39) \\
\hline 1 & 1 & Disdained by husband, two beds divide (Cupressus, 1:73) \\
\hline 1 & 1 & $\begin{array}{l}\text { Betrayed by the appearance of progeny after clandestine relations } \\
(\text { Osmunda, 1:93)* }\end{array}$ \\
\hline 1 & 1 & Gentle, tender as a lamb (Polypodium, 1:247)* \\
\hline 1 & 1 & Retiring, pursued by plighted swain (lichen, 1:293)* \\
\hline 1 & 1 & Intrepid wife seeking her spouse (Ulva, 1:353)* \\
\hline 1 & 1 & Hapless lover, killed by snow and cold (Tremella, 1:373)* \\
\hline 1 & 1 & Sings of her secret loves (Fucus, $4: 159)^{*}$ \\
\hline 1 & 1 & Awakened by enamored lover (Muschus, 4:259)* \\
\hline 1 & 1 & Impatient for her lover (Conferva, 4:269)* \\
\hline 1 & 1 & Chaste daughter who avows her love to husband (truffle, $4: 297)^{*}$ \\
\hline 1 & 1 & Strikes a talisman that charms husband (Caprificus, $4: 327$ )* \\
\hline 1 & 1 & Blooming bride (Byssus, 4:357)* \\
\hline 1 & 1 & Playful bride (Conferva, $4: 363)^{*}$ \\
\hline
\end{tabular}

II. More than one male and one female

\begin{tabular}{lll}
\hline 2 & 1 & A pitying beauty who soothes in turns (Collinsonia, 1:51) \\
2 & 1 & Tearful, calls her faithless lover (Vallisneria, 1:341) \\
2 & 1 & Baleful queen-sorceress (Circaea, 3:6) \\
3 & 1 & Has unjealous husbands (Iris, 1:71) \\
3 & 1 & Two houses hold a fashionable pair (Osyris, 1:75) \\
3 & 1 & Enthroned queen who grants gift of fame (Papyrus, 2:105) \\
4 & 1 & Adored by 2 knights, attended by 2 squires (Melissa, 1:59) \\
4 & 1 & Ambitious, soars and flies like an eagle (Visca, 1:225) \\
4 & 1 & Revived from faint by attentive youths (Dypsaca, 1:307) \\
4 & 1 & Blushing beauty, blending dye in cauldron (Rubia, 1:321) \\
4 & 1 & Protected from the throng by her helpers (Digitalis, 2:419) \\
4 & 1 & Flings poisoned darts and stings (Urtica, 3:191) \\
4 & 1 & Modest virgin (Trapa, 4:169) \\
5 & 1 & Laughing belle with a wanton air (Meadia, 1:61) \\
5 & 1 & Cold and shy, an obdurate beauty (Curcuma, 1:65) \\
5 & 1 & Reigns with charms despotic (Chondrilla, 1:97) \\
5 & 1 & A plumed lady who leads a gaudy band (Helianthus, 1:191) \\
5 & 1 & A fair lady with artless grace (Lonicera, 1:211) \\
5 & 1 & A fair mechanic, lady balloonist (Carlina, 2:7) \\
5 & 1 & Gentle timekeeper watching over the year (Lapsana, 2:163) \\
5 & 1 & A bright lady with golden hair (Calendula, 2:164) \\
5 & 1 & Priestess offering votaries to health (Cinchona, 2:343) \\
5 & 1 & Frantic queen, avenges rejected love by killing infants (Impatiens, \\
& & 3:131)
\end{tabular}

Note: The numbers in parentheses refer to the canto and the initial line number (see also n. 31). For clarity, the table has been divided in sections according to the relative number of stamens and pistils. The cryptogamia, in section I, are marked by an asterisk. 
Table 1. (Continued)

\begin{tabular}{|c|c|c|}
\hline $\begin{array}{c}\text { No. of } \\
\text { males } \\
\text { (stamens) }\end{array}$ & $\begin{array}{l}\text { No. of } \\
\text { females } \\
\text { (pistils) }\end{array}$ & Image \\
\hline \multicolumn{3}{|r|}{ II. More than one male and one female, cont'd } \\
\hline 5 & 1 & Her contagious breath brings death (Lobelia, 3:193) \\
\hline 5 & 1 & Seductive harlot (Vitis, $3: 287$ ) \\
\hline 5 & 1 & Gentle, grieving for dead baby (Cyclamen, $3: 311)$ \\
\hline 5 & 1 & Goddess with a train of cherubs (Bellis, $4: 113$ ) \\
\hline 6 & 1 & Ensnares with harlot smiles and wily charms (Gloriosa, 1:119) \\
\hline 6 & 1 & Folds her infant in her arms (Tulipa, 1:171) \\
\hline 6 & 1 & A tall beauty who casts her shadow on distant lands (Draba, 1:219) \\
\hline 6 & 1 & Playful beauty (Galanthus, 4:103) \\
\hline 8 & 1 & Chaste, saintlike (Tropaeolum, 4:43) \\
\hline 10 & 1 & Haughty maid wooed by brothers (Genista, 1:57) \\
\hline 10 & 1 & Stalks with gloomy dignity (Dictamnus, $3: 184$ ) \\
\hline 10 & 1 & A beauty guarded by fond brothers (Cassia, 3:343) \\
\hline 10 & 1 & African beauty in transparent clothes (Hedysarum, 4:237) \\
\hline 20 & 1 & Wild priestess/seer (Laurocerasus, 3:39) \\
\hline 20 & 1 & Breathes her virgin vows (Cerea, $4: 15$ ) \\
\hline 100 & 1 & Desdemona, won by sooty monster (Plantago, 1:77) \\
\hline many & 1 & Gigantic nymph reigning over puny lovers (Kleinhovia, 1:157) \\
\hline many & 1 & Queen of the coral groves (Zostera, 1:231) \\
\hline many & 1 & Queen of the seraglio (Mimosa, 1:267) \\
\hline many & 1 & Nymph encouraging factory operations (Gossypia, 2:85) \\
\hline many & 1 & Fair (Nymphaea, 2:163) \\
\hline many & 1 & Leads a sprightly troop (Cistus, $2: 301$ ) \\
\hline many & 1 & Keeper of fragrant treasures (tea, $2: 473$ ) \\
\hline many & 1 & Amazonian beauty (Arum, 4:187) \\
\hline
\end{tabular}

III. One male and more than one female

\begin{tabular}{rrl}
\hline 1 & 2 & \multicolumn{1}{c}{ Virgins smitten by beauty (Callitriche, 1:45) } \\
\hline 2 & 2 & \multicolumn{1}{c}{ IV. Multiple males and females } \\
3 & 2 & Shepherdess sisters and wives (Anthoxa, 1:85) \\
4 & 2 & Chaste sister-nymphs (Avena, 4:73) \\
10 & 2 & Burn with unallowed desires (Dianthus, 4:207) \\
12 & 2 & Sister-nymphs (Menispermum, 2:227) \\
6 & 3 & Blushing maids (Colchica, 1:181) \\
10 & 3 & Harlot band (Silene, 1:131) \\
4 & 4 & Sister-wives (Ilex, 1:143) \\
5 & 5 & A queen with 4 sister-nymphs (Drosera, 1:199) \\
5 & 5 & An inventor with 4 sister-nymphs (Flax, 2:67) \\
10 & 5 & Wanton beauties in gay undress (Lychnis, 1:107) \\
many & many & Glittering throng of beaux and belles (Anemone, 1:263) \\
many & many & Gay sisters with seductive smiles (Helleborus, 2:199) \\
many & many & Sorceress, sofa'd on silk (Papaver, 2:265) \\
many & many & A hundred blushing virgins (Adonis, 4:387) \\
\hline
\end{tabular}


however, no useful purpose would be served by duplicating the miscellaneous order of Darwin's verses, and sections I to IV are consequently arranged solely by the numbers involved. Within each section the entries are tabulated in the order in which they appear in the poem, with the canto and initial line number given in parentheses.

Turning to the first section of the table, where the numbers of the sexes are equal, we see that Darwin depicted a wide range of possible situations encompassed by courtship and marriage. His opening scene concerning the canna lily is significant in that it shows the couple in an idealized, romantic light: the female is a "timorous beauty," fragile and tremulous, unaccustomed to the British climate, dreading the "rude blast of Autumn's icy morn"; the male is defensive and tender in his actions, clasping his bride in his arms. The reader is invited to see this as a love match, against which situations and behavior in the rest of the poem can be measured.

The following verses describe other forms of relationship, indicating that Darwin was well aware of the wide range of feelings that draw or hold people together. Of the married state itself, his images amply reflect what Lawrence Stone has called the companionate marriage, in which the relations between the sexes depended on a greater sense of equality and sharing than was common previously. Though Stone's taxonomy has been strongly criticized in recent years for its failure to cover fully the realities of marriage and family life in the seventeenth and eighteenth centuries, it perhaps remains a valid concept in discussing a possible image of marriage in Darwin's time. ${ }^{47}$ These married women (or those who were otherwise possessed of only one partner) were described by Darwin in terms conventional to his time: they were "impatient" for their lovers, "playful," "chaste," "gentle," and "blooming"; they sought "talismans" to charm their husbands, or sang of their "secret love."

Extending the range of these conventional images, Darwin also mentioned in passing women with marital problems. One woman (Ulva) seeks her long-gone husband by sailing over the ocean, another is betrayed by a clandestine child (Osmunda). But among Darwin's characterizations of partnership some ideas that might have been expected on the strength of reading plays or novels of the time are missing: material benefits or possible financial incentives for marriage are never mentioned in the verses; divorce or separation hardly appears (although mutual dislike is represented by the plant Cupressus ${ }^{48}$ portrayed as a couple who share the same roof but occupy separate beds); adultery (apart from Osmunda) does not feature, either. Of course, it was hardly Darwin's intention to write of real life in the full sense. The point for historians here is rather that the presence or absence of certain features of eighteenth-century existence indicates just how completely Darwin was using the idealized pictures of his time in describing human relationships.

The next section of the table shows Darwin's descriptions of situations in which a single woman (pistil) coexists with more than one male (stamen). With small numbers of males, from say two to four, the female is shown by Darwin not as a wife this time but as a helpmate or associate, or as a figure not necessarily

${ }^{47}$ Lawrence Stone, The Family, Sex, and Marriage in England, 1500- 1800 (London: Weidenfeld \& Nicolson, 1977), pp. 325-404; and Linda A. Pollock, Forgotten Children: Parent-Child Relations from 1500 to 1900 (Cambridge: Cambridge Univ. Press, 1983).

${ }^{48}$ Darwin, Loves of the Plants, canto 1, lines 73-74 (p. 8). 
needed by the men at all, who may have other bonds such as those of scholarship or brotherhood to support their personal life.

Toward the five-to-six mark, Darwin became more explicit about female sexuality and described the woman with this number of suitors as being seductive or wanton in her charms. There is something of the sense of polite comedy or the stage plot in this, for at a certain point in the story his readers would expect a new kind of "character" to enter. In the poem, as in contemporary drama, the scene was set for the entrance of a very different sort of woman. Like Meadia, the American cowslip, she was a hoyden:

Meadia's soft chains five suppliant beaux confess,

And hand in hand the laughing Belle address;

Alike to all, she bows with wanton air,

Rolls her dark eye, and waves her golden hair. ${ }^{49}$

What counts here is not so much the predictable terms in which the "laughing Belle" is described but the exact moment at which she appears. The species Melissa and Trapa, in which the single pistil has four male associates, were not characterized as wanton. Vitis, also with five males, and Gloriosa, with six, were "seductive harlots." The transition from what might be called "acceptable" to "promiscuous" behavior hence takes place at a ratio somewhere around five to one, a point of view remarkable even in the eighteenth century for its perception of female sexual activity as an essentially "natural" phenomenon.

If she is not described as a houri or a flirt, the woman with so many males is shown as a person needing protection, with the males supplying the protection rather than being the objects from which the lady needs to be saved. Digitalis, the foxglove, invokes this kind of description: she has gifts of healing that are preserved and treasured by her male companions, in order-in Darwin's lines at least-to restore another, dropsical man to health:

Divine Hygiea, from the bending sky

Descending, listens to his piercing cry;

Assumes bright Digitalis' dress and air,

Her ruby cheek, white neck, and raven hair;

Four youths protect her from the circling throng,

And like the Nymph the Goddess steps along.-

O'er him she waves her serpent-wreathed wand,

Cheers with her voice, and raises with her hand,

Warms with rekindling bloom his visage wan,

And charms the shapeless monster into man. ${ }^{50}$

The female who is catalogued with eight or more males, however, leaves this divalent imagery behind and takes on unambiguous metaphors of power and command, being pictured as a saint, a reigning sovereign, a sorceress, a protoindustrialist mixing vermillion dyestuffs, a priestess, and so on, through the Linnaean classes up to that of Icosandria, with twenty stamens (beyond which Linnaeus does not direct botanists to count), and on to Polyandria, where there are from twenty to a hundred stamens in the same flower with the pistil. In this group

${ }^{49} \mathrm{Ibid}$., canto 1 , lines 61-64 (p. 6).

${ }^{50}$ Ibid., canto 2, lines 419-428 (pp. 78-79). 
there is a stern Amazonian beauty, the Arum or cuckoopint, who "trails her long lance, and nods her shadowy plumes," while

Wolves, bears and pards forsake the affrighted groves,

And grinning Satyrs tremble as she moves. ${ }^{51}$

And an inspired Pythian priestess, the "Lauro-cerasus" or cherry laurel:

With maniac step the Pythian Laura moves;

Full of the God her labouring bosom sighs,

Foam on her lips, and fury in her eyes,

Strong writhe her limbs, her wild dishevel'd hair

Starts from her laurel-wreath, and swims in air.-

While twenty Priests the gorgeous shrine surround

Cincture'd with ephods, and with garlands crown'd,

Contending hosts and trembling nations wait

The firm immutable behests of Fate. ${ }^{52}$

Other females are seen as fairy sovereigns pledged to virginity, as leaders of a sprightly troop of choristers, and so forth, as indicated in the table.

Section III shows one male coexisting with two females, the only instance in botany of there being more pistils than stamens. Darwin's metaphor, which presents two women gently caring for one beautiful youth, is devoid of sexuality. ${ }^{53}$ Powerful conventions govern the depiction of the women here, conventions running through the literature and drama of the period, in which women are seen as items of property, competed for but not duplicated. Rather than envisage the assemblage of one man and two women in a sexual context, Darwin chose to locate it in a neutral, possibly even familial relationship that secured the principals from any erotic connotation.

In the poem Darwin also worked through those parts of the Linnaean system where there are multiples of each sex. The fourth section of the table indicates that he was perhaps more interested in showing pastoral or mythological scenes than in characterizing individual men or women, but he still deployed images derived from the world of morals, as in his account of Silene, the catchfly, with three females and ten males in each flower, whose sticky nets for catching flies are likened to the deadly activities of three "dread sirens," skilled in destruction. ${ }^{54}$ The poppy is seen as a sultry oriental queen surrounded by a helpless throng of enchanted young people, all made languorous and empty by continued opium eating. ${ }^{55}$ Others are variously harlot-nymphs or gentle shepherdesses, blushing maids or sisters, with no apparent logic behind the imagery beyond the botanical properties of the plants themselves yet still presenting a fine succession of pictures of women in society.

Darwin's final scene endeavored to place all these varied pictures into a single frame. His choices of setting and the imagery used were evidently intended to provide the key to the way in which he hoped the poem would be considered and

51 Ibid., canto 4, lines 190, 205-206 (pp. 148-149).

52 Ibid., canto 3, lines 40-48 (pp. 92-93).

53 Ibid., canto 1, lines 45-50 (p. 4).

54 Ibid., canto 1, lines 131-142 (p. 14).

55 Ibid., canto 2, lines 265-290 (pp. 69-70). 
remembered, perhaps even a veiled reference to the metaphysical position embodied within it. Darwin chose to describe the fertilization of plants belonging to the Linnaean class Polyandria as if it were a Tahitian marriage ceremony, invoking the idea that human bonding was no more sacred than the purely physical meetings of stamen and pistil. Based on a close reading of the scientific and popular literature emanating from James Cook's and Joseph Banks's famous encounter with South Sea Island life, and steeped in an idealized view of Tahitians as untarnished natural beings whose society functioned admirably according to what Darwin perceived as 'natural,' non-Christian behavior, ${ }^{56}$ Darwin's anecdote served to remind readers that his poem was constructed around the idea that human actions in the realm of love were, in reality, natural phenomena and not owing to attributes bestowed by a creator. Darwin wrote of the Areoi people engaging in one great nuptial ceremony:

A hundred virgins join a hundred swains, And fond Adonis leads the sprightly trains;

Pair after pair, along his sacred groves

To Hymen's fane the bright procession moves;

As round his shrine the gaudy circles bow, And seal with muttering lips the faithless vow, Licentious Hymen joins their mingled hands, And loosely twines the meretricious bands.Thus where pleased Venus, in the southern main, Sheds all her smiles on Otaheite's plain, Wide o'er the isle her silken net she draws, And the Loves laugh at all, but Nature's laws. ${ }^{57}$

This was the overall image intended to be left in the mind of the reader. Such pronounced naturalism did not, however, lead Darwin to prescribe a sexual freefor-all in England; complete subjugation to the animal (and plant) passions was characteristic only of animals and plants, not humans. But he wished to set out the materialist point that human love and feelings about sexual relations were ultimately rooted in physiology not in Christianity. This idea was also to lie at the heart of his deistic-possibly even atheistic_philosophies of nature and society in The Economy of Vegetation and The Temple of Nature.

\section{WOMEN IN ARCADY}

Although Darwin hoped only to make Linnaean ideas about plant sexuality clear and attractive to readers by modeling it on human society, he nevertheless provided a catalogue of his own social world which deserves wider historical attention. In his poem Darwin listed a procession of female images ranging from virtuous brides and tender mothers to attentive sisters, nymphs, and shepherdesses. Laughing belles and wily charmers were followed by queens and amazons. Despite the robust sexuality and obvious insistence on 'natural' behavior, the overall impression is of an 'artificial' world far removed from real life. There are no

56 Walter Veit, ed., Captain James Cook: Image and Impact: South Sea Discoveries and the World of Letters (Melbourne: Hawthorne, 1972); and O'Brian, Joseph Banks (cit. n. 22); see also Harold B. Carter, Sir Joseph Banks 1743-1820 (London: British Museum [Natural History], 1988).

57 Darwin, Loves of the Plants, canto 4, lines 287-390, 399-406 (pp. 164-165). 
doubts or struggles with conscience in The Loves of the Plants. There are no sexual victims, no rape or violence of the kind found in Ovid or, for that matter, in some of Linnaeus's work. ${ }^{58}$ There is little sexual jealousy, no murder, vice, abortion, prostitution, death or disease, no heartbreaks or abandoned loversexcept for the victims of the harlot band-and only one instance of a clandestine child. All is clean, healthy, and pastoral. Rather like the images of women on the Portland vase, itself a topic of much interest to Darwin, or in the frontispieces to each of the poems that together go under the title The Botanic Garden (Figs. 3 and 4), the world that Darwin was describing was the world imagined by classically educated gentlefolk of the late eighteenth century, in which Flora and Cupid gaily exchange the tools of their trade (see Fig. 4) and reality is temporarily forgotten in a rustic poetic paradise. ${ }^{59}$

Darwin took pains to explain some of his intentions in the prose interludes between cantos. There he put forward the theory that poetry consists of a series of pictures set in a landscape affording graceful and apposite imagery-a theory that he evidently followed closely in The Loves of the Plants. In the "proem" he explained:

Whereas P. Ovidius Naso, a great Necromancer in the famous Court of Augustus Caesar, did by art poetic transmute Men, Women, and even Gods and Goddesses, into Trees and Flowers; I have undertaken by similar art to restore some of them to their original animality, after having remained prisoners so long in their respective vegetable mansions; and have here exhibited them before thee. Which thou may'st contemplate as diverse little pictures suspended over the chimney of a Lady's dressing-room, connected only by a slight festoon of ribbons. ${ }^{60}$

The poet, in Darwin's view, writes principally to the eye, in the sense that he or she creates pictures in the imagination. ${ }^{61}$ Abstract thoughts and complex trains of reasoning that cannot be visualized are best expressed in prose writings; and Darwin followed his own recommendations by confining the philosophical comments and explanations of his botanical poetry to lengthy prose footnotes and interludes, and to his meticulously ordered scientific writings, the Zoonomia and Phytologia. Prose was the vehicle for what Darwin called the "strict analogies of philosophy" as opposed to the looser analogies with which he and other versifiers "dress out the imagery of poetry." 62 In setting The Loves of the Plants in a garden and personifying flower parts he deployed instantly recognizable and attractive metaphors, providing a mental landscape that stimulated readers to create their own personal pictures.

Darwin's description of the cantos as largely a display of poetic pictures makes

58 See Karl Robert van Wikman, Lachesis and Nemesis: Four Chapters on the Human Condition in the Writings of Carl Linnaeus (Scripta Instituti: Donneriani Aboensis, 4) (Stockholm: Almquist \& Wiksell, 1970); $: \rightarrow$ Wolf Lepenies, "Linnaeus's Nemesis divina and the Concept of Divine Retaliation," Isis, 1982, 73:11-27; see also Sten Lindroth, "The Two Faces of Linnaeus," in Linnaeus: The Man and His Work, ed. Tore Frängsmyr (Berkeley/Los Angeles: Univ. California Press, 1983).

${ }_{59}$ Darwin discussed the Portland, or Barberini, Vase at length in the Economy of Vegetation (cit. n. 5), Additional Notes, pp. 53-59. In his opinion the figures represented scenes from the Eleusinian mysteries, consisting of an emblem of death in the first compartment and of immortal life in the second. The relief on the bottom of the vase he believed to be of a priestess, placed there as an emblem of secrecy or caution to the initiated. See $\varepsilon \rightarrow$ Irwin Primer, "Erasmus Darwin's Temple of Nature: Progress, Evolution, and the Eleusinian Mysteries," J. Hist. Ideas, 1964, 25:58-76.

${ }^{60}$ Darwin, Loves of the Plants, p. vi.

${ }^{61}$ See esp. McNeil, "Scientific Muse" (cit. n. 3).

${ }^{62}$ Darwin, Loves of the Plants, p. i. 
him here the poetic equivalent of a genre painter or, more appropriately, a landscape gardener-like Humphry Repton, who created an air of natural harmony, balance, and beauty by encouraging the landscape to reveal its features from artfully selected viewpoints that "frame" the resulting "picture." The theory of the picturesque followed by Uvedale Price and modified somewhat by Repton was expressly intended to improve on natural scenery through a study of the best landscape pictures, ${ }^{63}$ although Repton always maintained that nature and art should be recognized as different entities, following distinct sets of rules. Repton consciously used this distinction to create the pleasant tricks and confusions that emerge from a careful juxtaposition of real and cultivated nature. ${ }^{64}$ His desire to hide the boundary of a park or lawn and the facility with which he maintained the illusion that grounds extended in every direction from a house show a commitment to the creative involvement of the imagination of the viewer that mirrors the philosophy of mind held by Erasmus Darwin: the two men provided the topography, the skill, and the imagery in order to arouse in the mind of the spectator a train of analogies that created satisfying pictures. ${ }^{65}$ For them, as for others of the time, art was indeed artful; gardens and landscapes were graceful artifices that displayed nature at her best; cultivation did not signify the drudgery of the farmyard but rather the fostering of the gentle world of polite society. Darwin's poem, like Repton's sumptuously illustrated landscape designs, presented a series of views in which the subjects were carefully arranged to give the desired naturalistic and picturesque effect. ${ }^{66}$

The women that Darwin created were therefore entirely appropriate for the pastoral setting he envisaged. With one exception, there are no intellectual women in Darwin's verses, no educated poetesses like Anna Seward; no artists like Angelica Kaufmann (who is only mentioned in passing in one of the prose interludes); ${ }^{67}$ no one like Maria Edgeworth, well known personally to Darwin as a girl; ${ }^{68}$ no Mary Wollstonecraft or Madame de Staël. Even though there is some account of women with power or special knowledge, and of certain intrepid females such as the lady balloonist (Carlina, the thistle) and the nymph who turns the waterwheels for the cotton manufacturing industry on the river Derwent, ${ }^{69}$

${ }^{63}$ The key text here was William Gilpin, Observations Relative to Picturesque Beauty (London, 1786). See Ann Bermingham, Landscape and Ideology: The English Rustic Tradition 1740-1860 (London: Thames \& Hudson, 1987), for a full bibliography.

${ }^{64}$ Humphry Repton, Observations on the Theory and Practice of Landscape Gardening (London, 1805); and Repton, Variety: A Collection of Essays (London, 1788); see also The Red Books of Humphry Repton: Facsimiles of the Red Books for Sherringham in Norfolk, Antony House in Cornwall, Attingham in Shropshire, 4 vols. (London: Basilisk Press, 1976).

${ }^{65}$ There is a sizable literature on the interconvertibility of the pictorial, poetic, and landscape arts, and on the belief common during the 1780s and 1790s that this was an important philosophical movement. See esp. John Barrell, The Idea of Landscape and the Sense of Place (Cambridge: Cambridge Univ. Press, 1973); and John Dixon Hunt, The Figure in the Landscape: Poetry, Painting, and Gardening during the Eighteenth Century (Baltimore/London: Johns Hopkins Univ. Press, 1976).

${ }^{66}$ In Loves of the Plants, p. 40, Darwin wrote: "I am only a flower-painter, or occasionally attempt a landskip; and leave the human figure with the portraits of history to abler artists." Darwin's friend Anna Seward knew Humphry Repton personally; see Repton, Variety (cit. n. 64).

${ }^{67}$ Darwin, Loves of the Plants, pp. 45, 49. Three other women artists are mentioned: Mrs. Delaney, who prepared paper mosaic pictures of flowers according to Linnaeus's system (pp. 61-62); Mrs. North, the flower painter (p. 62); and Miss Emma Crewe, who drew the frontispiece (Fig. 4) and is praised by Darwin, pp. 70-71.

${ }_{68}^{6}$ Letters of Erasmus Darwin, pp. 338-339.

${ }^{69}$ Darwin, Loves of the Plants, canto 2, lines 7, 85 (pp. 52-55, 56-58). 
there are no descriptions of intelligent, literary women of the kind prominent in his own life and in late eighteenth-century society as a whole.

The one apparent exception is the narrator herself, the goddess of botany, the didactic lecturer who speaks the whole poem. She is not only an expert botanist but also displays a deep and varied knowledge of contemporary science and the world about her. By choosing such a voice for his work, Darwin apparently demonstrated his genuine regard for educated women. But in fact this knowledgable goddess would not have been perceived in this way, for it was impossible for any reader of the time to have believed that the author was indeed a $v$ Darwin may have been free to write a poem about sexual conduct, but his

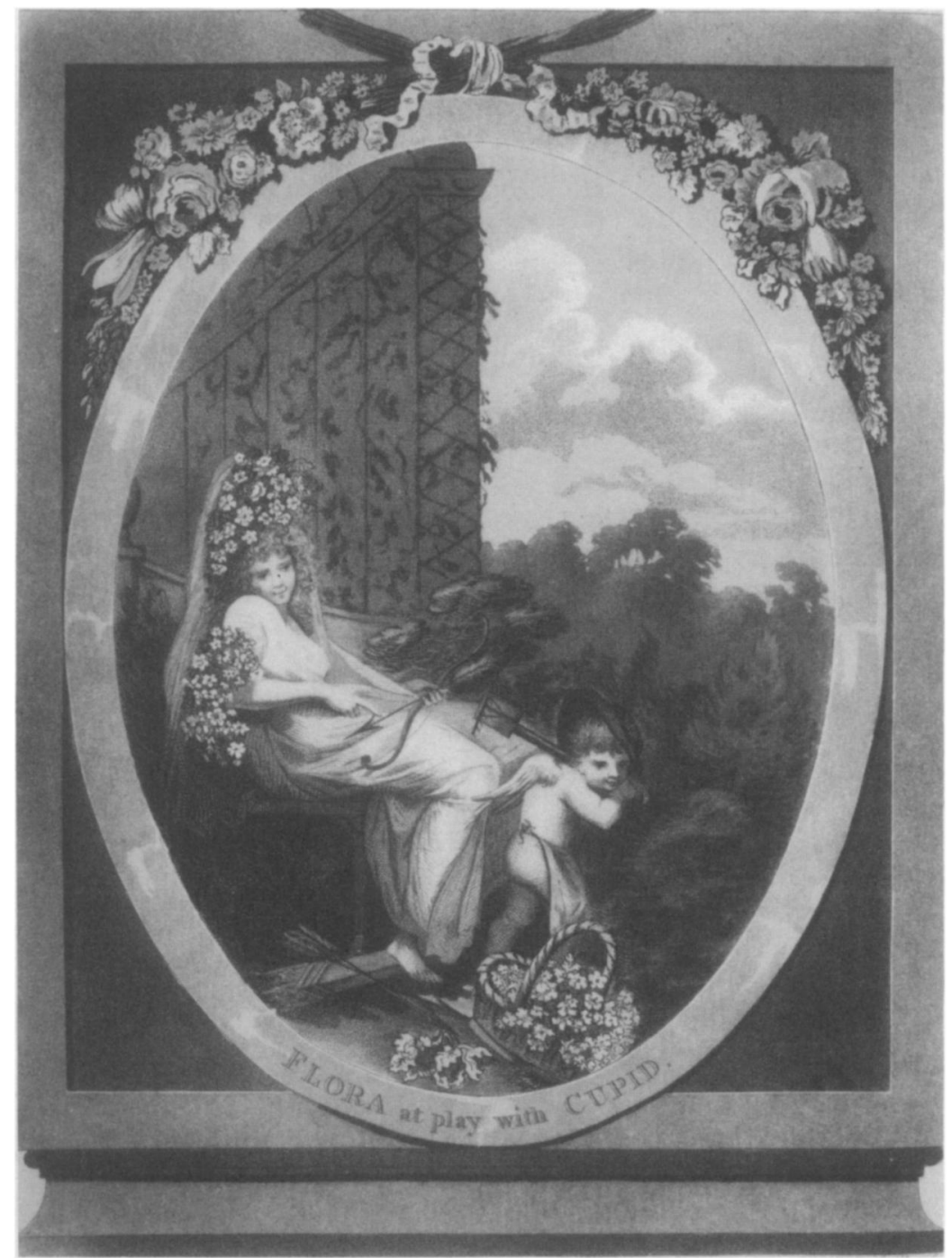

Figure 4. "Flora at play with Cupid," designed by Emma Crewe and engraved by S. Alken, 1791. The frontispiece to Erasmus Darwin, The Loves of the Plants, Part II of The Botanic Garden (London, 1792). Reproduced courtesy of the Wellcome Institute Library. 
counterpart would not have dared to do the same. The disguise was clearly transparent: the botanic muse turns out to be a man.

The absence of educated women in the poem does not in itself betoken Darwin's dislike of them or any deeper views on sexual inequalities in nature. For one thing, his poetic Arcady had little room for intellectuals of either sex: if there was no Lady Hester Stanhope, there was no Dr. Johnson either; both would have had a hard time masquerading as shepherds. Darwin's intentions and the deliberate frame in which he cast his images provided only a limited, preconceived range of metaphor into which certain categories would not be allowed..$^{70}$ Furthermore, we know, for example, that Darwin argued for the better education of women, devised a progressive and liberal scheme for a girls' boarding school, ${ }^{71}$ and endorsed an extraordinary Pygmalion plan carried out by his friend Thomas Day to educate a foundling girl to such a pitch that she would make a perfect Mrs. Day. ${ }^{72}$ Yet (as this last project suggests) like most of the men of his time and social position who advocated a better education for women, Darwin saw it primarily in terms of the benefit to men. Education should produce "a good daughter, a good wife, and a good mother, that is, an amiable character in every department of life." Moreover, the female character "should possess the mild and retiring virtues rather than the bold and dazzling ones; great eminence in almost any thing is sometimes injurious to a young lady." 73 Entirely in accord with other male writers on women's education, Darwin wished to enlarge the world that women negotiated, yet the choices he wished women to make were still circumscribed and favored the maintenance of contemporary society and, in particular, the status quo of contemporary men. Similarly, the images in The Loves of the Plants, for all Darwin's progressive views, remained deeply polarized between the chaste, blushing virgin and the seductive predatory woman, the modest shepherdess and the powerful queen.

\section{BOTANY FOR GENTLEMEN}

In the end Darwin's personal attitude to women or their emancipation is less significant than the limited and entirely traditional nature of his images, which reflect more generally held views about women and the relations between the sexes. Given that Darwin was personifying a particular scientific classification scheme in order to make it attractive and easily memorable, it is only to be expected that he would choose metaphors instantly recognizable, familiar, and memorable in their own right. He presented pictures of women that were for many people reassuring stereotypes: the images that his contemporaries-both

70 James Venable Logan, The Poetry and Aesthetics of Erasmus Darwin (Princeton Studies in English, 15) (Princeton, N.J.: Princeton Univ. Press, 1936), pp. 46-92; and Hassler, The Comedian as the Letter D: Erasmus Darwin's Comic Materialism (The Hague: Martinus Nijhoff, 1973).

${ }^{71}$ Erasmus Darwin, A Plan for the Conduct of Female Education in Boarding Schools (Derby/ London, 1797). The school was run by Darwin's two natural daughters, Susan and Mary Parker; see Letters of Erasmus Darwin, pp. 270-271; and E. Posner, Darwin and the Sisters Parker (cit. n. 46).

72 Seward, Memoirs (cit. n. 30), pp. 35-51. The girl, called Sabrina, did not rally to Day's Rousseauean ideals and was eventually placed in a boarding school in Sutton Coldfield, whence she married a friend of Day's. See also Keir, Life and Writings of Thomas Day (cit. n. 6), pp. $27-29$.

${ }^{73}$ Darwin, Female Education (cit. n. 71), pp. 47, 10. The plan is explained as being designed to equip girls for life in polite society, especially if their male support should fail (pp. 52, 55). 
male and female-were accustomed to finding in the romantic novels, pastoral poetry, and dramatic arts patronized by the landed gentry. It is in this sense that one might suggest that Darwin's scheme was basically patriarchal and that his botany was botany for gentlemen, rather than for ladies. Deliberately directed to "lady readers," The Loves of the Plants elaborated a series of views designed to reinforce women's roles as sexual partner, friend, wife, and mother, promoting the view that these stereotypes were in some sense "natural," built into the physiology or structure of women. Intentionally or not, the poem conveys a masculine view of what was considered appropriate feminine behavior.

To some extent it is therefore possible to locate Darwin's poem in the dark transformations in sexual feelings that Michel Foucault describes, from the "bright day" of seventeenth-century sexuality to the "monotonous nights" of the Victorian bourgeoisie. ${ }^{74}$ For Foucault, it is the things left unsaid that point the way to a deeper understanding of the views expressed in a text, and such an approach is clearly helpful in assessing Darwin's position on sexual relations and women's role in society. The Loves of the Plants can be seen as avoiding those areas where contemporary fears might have jolted or outweighed the overall ideas being presented; as expelling unwanted forms of behavior; and as ignoring the physical and emotional results of sexual activity in the real world. Darwin's catalogue of the behavior of the plants can signify a form of sexual regulation among humans. Certainly it represents a particular point in the complicated process of "naturalizing" the way that society considered the body, particularly the female body, and of rethinking the relations between god and nature, a process that took place gradually over the early modern period. ${ }^{75}$

Darwin's contribution to this process was not, however, based on fear, as a reading of Foucault might lead some to suggest. It is true that new studies reveal how his mentor Linnaeus may have exorcised his fears about the body by putting sex at the heart of his classification system and thereby rendering it neutral, or at least turning it into a "scientific" and hence more manageable commodity. ${ }^{76}$ But there was a world of difference between Linnaeus's and Darwin's personal life, the one a believer in divine retribution and a fierce, avenging, moralistic God, the other a liberal, freethinking deist with an obvious interest in the opposite sex. Rather than feeling anxious about sexual relations, Darwin undoubtedly relished them. Both his marriages were happy ones, by all accounts, and certainly fruitful: Darwin had three surviving (out of five) children by Mary Howard and seven by Elizabeth Pole. Nor did he, in the interval between marriages, feel any need to remain celibate. Living with Mrs. Parker, a widow of Lichfield, he fathered two natural daughters who continued to reside with him until fully grown. As an

\footnotetext{
${ }^{74}$ Michel Foucault, The History of Sexuality, trans. Robert Hurley, Vol. I: An Introduction (London: Allen Lane, 1979).

75 See Ruth Bleier, Science and Gender: A Critique of Biology and Its Theories on Women (Oxford: Pergamon Press, 1984); Brian Easlea, Science and Sexual Oppression: Patriarchy's Confrontation with Women and Nature (London: Weidenfeld \& Nicolson, 1981); Evelyn Fox Keller, Reflections on Gender and Science (New Haven, Conn.: Yale Univ. Press, 1985); Carol MacCormack and Marilyn Strathern, eds., Nature, Culture and Gender (Cambridge: Cambridge Univ. Press, 1980); and Ludmilla Jordanova, "Naturalizing the Family: Literature and the Bio-Medical Sciences in the Late Eighteenth Century," in Languages of Nature (cit. n. 3).

${ }^{76}$ Lepenies, "Linnaeus's Nemesis divina"; Lindroth, "Two Faces of Linnaeus" (both cit. n. 58); and Delaporte, Nature's Second Kingdom (cit. n. 7), pp. 139-140.
} 
unidentified obituarist remarked in 1803, Darwin could never forsake the charms of Venus. ${ }^{77} \mathrm{He}$ fits more happily into the British tradition of "rational" thought, keen to disclose the basic "laws of nature," to show the identity between plants, animals, and humans; and to demonstrate that all living beings were governed by the same physiological processes and indeed, in Darwin's case, how they were all linked together by one unbroken evolutionary chain. The classification of women that emerges from his classification of plants is important precisely because Darwin took a range of female feelings and activities and deliberately lifted them out of the world of traditional Western morals in order to relocate them in nature, represented in his poetry by the non-Christian world of antiquity and the island of Tahiti and made explicit by his use of the imagery of a botanic garden. He made sexuality a normal feature of human life, love a "natural law."

By personifying plants, Darwin was therefore offering an interpretation of nature that operated on many levels. At its most obvious, The Loves of the Plants encouraged readers to think of plant species as sophisticated living organisms that enjoyed all the benefits of human existence, most notably sexuality. Even if for nothing else, The Loves of the Plants was significant in the history of botany for its emphatic restatement of Linnaeus's doctrine of the sexuality of plants and for bringing this concept to the forefront of natural science during the 1790s. Few readers-James Edward Smith, Joseph Banks, Robert Thornton, Samuel Taylor Coleridge, William Wordsworth, and Charles Darwin among them-could afterwards forget that garden flowers had a sex life. This personalized, sexualized picture remained vivid through the early years of the nineteenth century: so vivid that many of the efforts of women botanists such as Priscilla Wakefield were directed to rendering the subject in more neutral terms, suitable for the new wave of feminine enthusiasts emerging in the pre-Victorian period. ${ }^{78}$ Successfully bowdlerized and sentimentalized, the image of plants as people lived on well past the turn of the century, particularly in literature directed toward women and children such as, for example, the well-known Flower Fairy Books, first published by Cicely Mary Barker in 1923.

Darwin also encouraged readers to see in his work a statement of the interconnectedness of the living world, a view first expressed in the translations of Linnaeus's Species plantarum and Genera plantarum: "For vegetables are, in truth, an inferior order of animals." 79 Plants were like animals because they possessed the same natural functions, different only in degree. The Loves of the Plants can therefore be seen as preliminary to, and closely intermeshed with, Darwin's later views on transformism and on the existence of an evolutionary chain of organisms stretching from molecules to man.

At another level entirely, Darwin's work took up views about human sexual and social behavior common to his personal intellectual circle and more generally to those of his class and wealth, and expressed them through the various images that the idea of personification generated. While it was not Darwin's intention to make great philosophical play with his metaphor, one consequence of this ex-

${ }^{77}$ King-Hele, Erasmus Darwin (cit. n. 2), p. 14.

78 Ann B. Shteir, "Priscilla Wakefield's Natural History Books," in From Linnaeus to Darwin: Commentaries on the History of Biology and Geology, ed. Alwyne Wheeler and James H. Price (Papers from the Fifth Easter Meeting of the Society for the History of Natural History, 28-31 March 1983) (London: Society for the History of Natural History, 1985).

${ }^{79}$ See Botanical Society of Lichfield, Families of Plants (cit. n. 20), p. xix. 
tended analogy was that as it became easier to think of plants as people so it became possible to think of human beings as plants. Like all metaphors in the history of science, ${ }^{80}$ Darwin's idea of the personification of plants allowed the fruitful interplay of ideas between one realm (the human) and another (the botanical). We know we are not plants, but it is both amusing and informative to think about why we are not. Darwin invited his readers to consider whether humans were solely natural beings or whether there were also higher spiritual qualities inherent to mankind. Darwin's pictures revealed that he believed only in nature, and the poem's organizing structure of a botanic garden served to allude to the possibility of a world without the Christian church, a view made more explicit in The Economy of Vegetation, issued only two years after The Loves of the Plants, and in The Temple of Nature. Part of this manipulation and interplay of images was that women were plainly seen as "natural" beings, their function being primarily reproductive, their behavior seen through a wide range of stereotypes that themselves were presented as "natural" roles.

Linnaeus's classification scheme was thus being used to project an interconnected nexus of personal and communal views, commitments, and judgments, many of which were subsequently worked out by Darwin in his evolutionary verse and other writings, but which never came together again in quite the same evocative combination of philosophical and social values. Darwin turned the sexual system of Linnaeus to his own purposes and made it embody his metaphysical beliefs, his scientific commitments, his social world, and the intellectual preoccupations and assumptions of the wealthy, freethinking, professional class to which he belonged-and also those of his gender. So although Ann Shteir and David Allen are quite right to exhort us to think of the study of plants as a particularly feminine, female, occupation ${ }^{81}$ it would be a pity, in the continuing search for "Linnaeus's daughters," to overlook this other kind of botany, botany for gentlemen.

${ }^{80}$ See esp. Andrew E. Benjamin, Geoffrey N. Cantor, and John R. R. Christie, eds., The Figural and the Literal: Problems of Language in the History of Science and Philosophy, 1630-1800 (Manchester: Manchester Univ. Press, 1987); Stanley Hyman, The Tangled Bank (New York: Atheneum, 1962); Jordanova, ed., Languages of Nature (cit. n. 3); Thomas, Man and the Natural World (cit. n. 43); and Robert M. Young, "Darwin's Metaphor: Nature's Place in Victorian Culture (Cambridge: Cambridge Univ. Press, 1985).

${ }^{81}$ Ann B. Shteir, "Linnaeus's Daughters: Women and British Botany" in Women and the Structure of Society: Selected Research from the Fifth Berkshire Conference on the History of Women, ed. Barbara J. Harris and JoAnn K. McNamara (Durham, N.C.: Duke Univ. Press, 1984), pp. 67-73; and

$\rightarrow$ David E. Allen, "The Women Members of the Botanical Society of London, 1836-1856," British Journal for the History of Science, 1980, 13:240-254. 